\title{
Nonlinear turnover rates of soil carbon following cultivation of native grasslands and subsequent afforestation of croplands
}

\author{
Guillermo Hernandez-Ramirez ${ }^{1}$, Thomas J. Sauer ${ }^{2}$, Yury G. Chendev ${ }^{3}$, and Alexander N. Gennadiev ${ }^{4}$ \\ ${ }^{1}$ Department of Renewable Resources, University of Alberta, Edmonton, AB, T6G2R3, Canada \\ ${ }^{2}$ USDA-ARS, National Laboratory for Agriculture and Environment, Ames, IA 50011, USA \\ ${ }^{3}$ Department of Natural Resources Management and Land Cadastre, Belgorod State University, \\ 85 Pobeda Street, Belgorod 308015, Russia \\ ${ }^{4}$ Lomonosov Moscow State University, Faculty of Geography, 119991, \\ Moscow, GSP-1, 1 Leninskiye Gory, Russia \\ Correspondence: Guillermo Hernandez-Ramirez (ghernand@ualberta.ca)
}

Received: 16 January 2021 - Discussion started: 12 February 2021

Revised: 4 June 2021 - Accepted: 18 June 2021 - Published: 19 July 2021

\begin{abstract}
Land use conversions can strongly impact soil organic matter (SOM) storage, which creates paramount opportunities for sequestering atmospheric carbon into the soil. It is known that land uses such as annual cropping and afforestation can decrease and increase SOM, respectively; however, the rates of these changes over time remain elusive. This study focused on extracting the kinetics $(k)$ of turnover rates that describe these long-term changes in soil $\mathrm{C}$ storage and also quantifying the sources of soil $\mathrm{C}$. We used topsoil organic carbon density and $\delta^{13} \mathrm{C}$ isotopic composition data from multiple chronosequences and paired sites in Russia and United States. Reconstruction of soil C storage trajectory over 250 years following conversion from native grassland to continual annual cropland revealed a $\mathrm{C}$ depletion rate of $0.010 \mathrm{yr}^{-1}$ (first-order $k$ rate constant), which translates into a mean residence time (MRT) of 100 years $\left(R^{2} \geq 0.90\right)$. Conversely, soil C accretion was observed over 70 years following afforestation of annual croplands at a much faster $k$ rate of $0.055 \mathrm{yr}^{-1}$. The corresponding MRT was only 18 years $\left(R^{2}=0.997\right)$ after a lag phase of 5 years. Over these 23 years of afforestation, trees contributed $14 \mathrm{MgCha}^{-1}$ to soil $\mathrm{C}$ accrual in the 0 to $15 \mathrm{~cm}$ depth increment. This tree-C contribution reached $22 \mathrm{MgCha}^{-1}$ at 70 years after tree planting. Over these 70 years of afforestation, the proportion of tree $\mathrm{C}$ to whole-soil $\mathrm{C}$ increased to reach a sizable $79 \%$. Furthermore, assuming steady state of soil C in the adjacent croplands, we also estimated that $45 \%$ of the prairie $\mathrm{C}$ existent at the time of tree planting was still present in the afforested soils 70 years later. As an intrinsic property of $k$ modeling, the derived turnover rates that represent soil $\mathrm{C}$ changes over time are nonlinear. Soil $\mathrm{C}$ changes were much more dynamic during the first decades following a land use conversion than afterwards when the new land use system approached equilibrium. Collectively, results substantiated that $\mathrm{C}$ sequestration in afforested lands is a suitable means to proactively mitigate escalating climate change within a typical person's lifetime, as indicated by MRTs of a few decades.
\end{abstract}




\section{Introduction}

The global effects of escalating climate change are in part driven by land use choices. Indeed, implementing certain land use changes can worsen or in other cases mitigate emissions of greenhouse gases from terrestrial ecosystems to the atmosphere (Paustian et al., 1992; Post and Kwon, 2000; Thilakarathna and Hernandez-Ramirez, 2021). Essentially, land use options that unintentionally accelerate biological oxidation of soil organic matter (SOM) contribute over time to atmospheric carbon dioxide concentrations (Sauer et al., 2007; Laganiere et al., 2010; Li et al., 2018), providing a portion of the radiative forcing that has been causing part of the global warming effect over the last decades (Guo and Gifford, 2002; Parry et al., 2007). Relative to contrasting types of land use systems, annual croplands commonly showed SOM depletion and marked reductions in soil $\mathrm{C}$ storage, in particular compared with their natural ecosystem counterparts (Chendev et al., 2015b; Hebb et al., 2017; Kiani et al., 2017).

Contrary to the potentially detrimental effects of annual cropping on SOM accumulation and overall soil quality (Guenette and Hernandez-Ramirez, 2018; Laganiere et al., 2010; Kiani et al., 2020), tree planting offers multiple environmental services and societal benefits (HernandezRamirez et al., 2012; Sauer et al., 2012; Zhang et al., 2020). For instance, removing $C$ from the atmosphere is a paramount contribution by trees (Guo and Gifford, 2002; Li et al., 2012, 2018). In effect, soil C accrual (Paul et al., 2002; Dhillon and Van Rees, 2017; Khaleel et al., 2020) and stabilization (Hernandez-Ramirez et al., 2011; Wang et al., 2016; Quesada et al., 2020) beneath trees have been recognized as an effective means of sequestering atmospheric $\mathrm{C}$. In addition to soil accruals, diverse microbial communities can flourish beneath mature trees (Kiani et al., 2017). Additional functions by tree vegetation include improving air quality, enhanced microclimate, and erosion control (Sauer et al., 2007; Hernandez-Ramirez et al., 2012; Chendev et al., $2015 b$ ). Establishing agroforestry practices such as shelterbelt systems within annual croplands can provide a balance between continual food production and tree benefits with only a fraction of the landscape occupied by trees (Amadi et al., 2016; Dhillon and Van Rees, 2017).

Sequestering $\mathrm{C}$ in soils is governed by the balance of inputs of plant $\mathrm{C}$ with decomposition and stabilization processes (Hernandez-Ramirez et al., 2009; Kiani et al., 2017; $\mathrm{Li}$ et al., 2018). This overall functioning of C-related biology and cycling in soils can be described as the turnover of soil C. Collectively, SOM mineralization, gains and losses, and net accrual can be numerically integrated into $\mathrm{C}$ turnover rates (Richter et al., 1999; Hernandez-Ramirez et al., 2011; Xiong et al., 2020). For instance, dynamic rates of net depletion of SOM pools caused by continual cropping or tree contributions to soil $\mathrm{C}$ accretion and cycling under afforestation can both be captured as C turnover rates (Guo and Gifford, 2002; Hu et al., 2013). Nevertheless, since using linear rates to describe changes in soil $\mathrm{C}$ often leads to poor estimates of $\mathrm{C}$ inventories and sequestration, soil $\mathrm{C}$ accrual rates need to be derived as nonlinear rates to accurately predict the trajectory of soil $\mathrm{C}$ changes with time following land use conversions (Post and Kwon, 2000; Garten, 2002). Moreover, the direction and net rates of SOM accrual as a response to land use changes need to be assessed in the long term (i.e., ranging from decadal to centurial scales) (Paustian et al., 1992; Hernandez-Ramirez et al., 2011). This new knowledge will inform how lasting these effects of land management options on soil C storage are, enabling predictions of future soil C sequestration (Richter et al., 1999; Guo and Gifford, 2002). Our study endeavors to address and fill these knowledge gaps.

Testing accrual rates of SOM is still lacking in the literature. Previous studies have evaluated soil $\mathrm{C}$ turnover rates as a function of changes in land management only over one or a few decades (Jastrow et al., 1996; Hernandez-Ramirez et al., 2011; Mary et al., 2020); however, the underlying assumption of asymptotic behavior in the rate of soil $\mathrm{C}$ change has rarely been verified over longer periods such as over centuries. Likewise, earlier studies examining dynamics of soil carbon in continuous annual croplands have suggested typical mean residence times (MRTs) of 117 years (Huggins et al., 1998) and 57 years (Collins et al., 1999); however, it is still unclear how long-term land use changes from native grasslands to annual croplands and from annual croplands into afforestation can impact the turnover rates of soil $\mathrm{C}$ over centuries.

In this study, we compiled soil C storage data from several field sites comparing land use systems in Russia and United States (Chendev et al., 2015a, b) in conjunction with published (Hernandez-Ramirez et al., 2011) and newly available soil ${ }^{13} \mathrm{C}$ isotope data. Based on these data assemblages, we now focus on evaluating the long-term turnover rates of soil $\mathrm{C}$ as a function of land use changes from native grasslands to annual croplands and subsequent converting annual croplands into afforestation. We aimed at extracting turnover rates of soil $\mathrm{C}$ depletion or accretion, which can enable future predictions of soil $\mathrm{C}$ storage depending on land use systems. Also, our study quantified and documented the contributions of tree-biomass $\mathrm{C}$ to soil $\mathrm{C}$ that was newly accrued following afforestation. We further examined the stage and net losses of the $\mathrm{C}$ that existed in the soil under annual croplands prior to tree planting.

\section{Materials and methods}

\subsection{Chronosequences from native grasslands to annual croplands in Russia}

Three long-term chronosequences of land use conversion (i.e., a range of different durations of cultivation) were used for extracting turnover parameters. These land use chronosequences were situated in Belgorod Oblast, Russia, within the districts of Prokhorovskiy (50 $\left.57^{\prime} \mathrm{N}, 36^{\circ} 44^{\prime} \mathrm{E}\right)$, Gubkinskiy 
$\left(51^{\circ} 03^{\prime} \mathrm{N}, 37^{\circ} 22^{\prime} \mathrm{E}\right)$, and Ivnyanskiy $\left(51^{\circ} 06^{\prime} \mathrm{N}, 36^{\circ} 24^{\prime} \mathrm{E}\right)$ as previously described by Chendev et al. (2015a) (Fig. 1). Following chronosequence methods as described by Laganiere et al. (2010), each chronosequence had four or five age/sites encompassing a native grassland site that represented the time zero of conversion from grassland to annual cropland. These native grasslands were undisturbed steppe dominated by plant species with $\mathrm{C}_{3}$ photosynthetic pathway. The ages of the cropland sites were established through historical records and geographic approaches described by Chendev et al. $(2012,2015 b)$. Additional information about the study sites is available at Chendev et al. (2015a), while the focus in our study remains on developing models and extracting parameters of $\mathrm{C}$ turnover rates. Typical crops species included cereals, sunflower (Helianthus annuus), and beet (Beta vulgaris) managed under conventional tillage operations. Within the study region, soils were classified as loamy Chernozems (Russian Soil Classification System); annual precipitation ranged between 480 and $580 \mathrm{~mm}$, and air temperature ranged between 5.3 and $5.8^{\circ} \mathrm{C}$ (Chendev et al., 2015a).

Composite soil samples (three subsamples per sample) with at least 12 sampling locations per age/site were collected using the core method in $10 \mathrm{~cm}$ depth increments to $1 \mathrm{~m}$ depth. Field moist soil samples were passed through 8 and $2 \mathrm{~mm}$ sieves, air dried, and ground with a roller mill (Bailey Manufacturing Inc., Norwalk, IA) to create a fine powder consistency. Identifiable plant materials were removed prior to grinding (Hernandez-Ramirez et al., 2011; Chendev et al., 2015b).

Soil organic $\mathrm{C}$ mass density for the 0 to $30 \mathrm{~cm}$ depth was calculated as the sum of products of organic $\mathrm{C}$ concentration (Hernandez-Ramirez et al., 2009), bulk density, and soil layer thickness, with units of megagrams of carbon per hectare $\left(\mathrm{Mg} \mathrm{Cha}^{-1}\right)$.

First-order kinetic modeling follows:

$\mathrm{C}_{(t)}=\mathrm{C}_{\mathrm{e}}+\left(\mathrm{C}_{o}-\mathrm{C}_{\mathrm{e}}\right) e^{-k t}$,

where $\mathrm{C}_{\mathrm{e}}$ is soil $\mathrm{C}$ storage at the oldest cropland site within each chronosequence, which was assumed to be at new dynamic equilibrium (i.e., $\mathrm{C}$ inputs $=\mathrm{C}$ outputs); $\mathrm{C}_{0}$ is soil $\mathrm{C}$ storage at the native grassland site, which was assumed to be the initial time of land use conversion from native grassland to annual croplands (time zero); $k$ is the fitted firstorder kinetic rate constant $\left(\mathrm{yr}^{-1}\right)$, which is equivalent to $\mathrm{C}$ turnover rate or net $\mathrm{C}$ mineralization (in the case of net $\mathrm{C}$ decreases); and $t$ stands for time (yr). In the case of increases in soil $\mathrm{C}$ over time, turnover rates become equivalent to accretion rates. It is possible to model the soil C storage for each year; hence, the difference between consecutive years provides an estimation of the annual net $\mathrm{C}$ change $\left(\mathrm{MgCha}^{-1} \mathrm{yr}^{-1}\right)$. First-order kinetic modeling (Eq. 1) assumes (i) a balance between $\mathrm{C}$ inputs and $\mathrm{C}$ outputs and (ii) steady-state conditions (i.e., $\delta \mathrm{C} / \delta t=0$ ) (Jastrow et al., 1996; Follett et al., 1997; Hernandez-Ramirez et al., 2011). At the various study sites, the terrain slopes ranged up to
$2 \%$, with the exception of the Huron site that had $3 \%$ slope. Hence, the general topography in our study sites was classified as flat. We assume that the semiarid climate, enough vegetation cover and low slope limit water and wind erosion. Given the dominant flat topography and low rainfall amounts, we also assumed negligible $\mathrm{C}$ removals or additions due to erosion or deposition.

Mean residence time (MRT) of organic $\mathrm{C}$ in the soil was calculated as reciprocal of $k$. Concomitantly, half-life of organic $\mathrm{C}$ in the soil was calculated as follows:

Half-life $=\ln (2) / k$.

Note that under equilibrium, $\mathrm{C}$ output $_{\mathrm{e}}$ is also equivalent to $\mathrm{C}$ inpute, and they correspond to the annual $\mathrm{C}$ that enters and exits the soil $\mathrm{C}$ pool, respectively.

The performance of the derived first-order kinetic modeling was evaluated with the normalized root-mean-square error (RMSEn) (Guenette and Hernandez-Ramirez, 2018; Kiani et al., 2020), coefficient of determination $\left(R^{2}\right)$, and a leave-one-out cross-validation of predicted versus measured $\mathrm{C}(n=6)$. Within the cross-validation, we tested the regression coefficient $\left(\beta_{1}\right)$ of a linear regression established for predicted vs. measured $\mathrm{C}$ against the $1: 1$ line.

\subsection{Comparison of adjacent paired sites in Russia: \\ native grasslands, annual croplands, and shelterbelts (trees)}

In addition to the three abovementioned chronosequences, three additional sites were studied in Russia: Streletskaya Steppe situated within Kursk Oblast $\left(51^{\circ} 32^{\prime} \mathrm{N}, 36^{\circ} 05^{\prime} \mathrm{E}\right)$, Yamskaya Steppe in Belgorod Oblast $\left(51^{\circ} 11^{\prime} \mathrm{N}, 37^{\circ} 37^{\prime} \mathrm{E}\right)$, and Kamennaya Steppe in Voronezh Oblast $\left(51^{\circ} 02^{\prime} \mathrm{N}\right.$, $40^{\circ} 44^{\prime}$ E) (Fig. 1). Soils at all these paired sites were classified as loamy Chernozems. Following field methods as described by Laganiere et al. (2010), each site encompassed adjacent locations representing three land uses: native grassland, annual croplands, and broadleaf shelterbelts, as described by Chendev et al. (2015b). Soil sample collections were conducted similarly as described above. Briefly, composite soil samples (three subsamples per sample) were collected from the native grassland $(n=6$ composite soil samples), annual croplands (24), and shelterbelts (18) in summer 2012. At the time of soil sample collection, the ages of the annual croplands in Streletskaya and Yamskaya were at least 140 years and at least 145 years of age in Kamennaya. In all three sites, the shelterbelts had been planted 55 years prior to soil sample collection. Tree species in the shelterbelts include silver birch (Betula verrucosa), Manitoba maple (Acer negundo), and English oak (Quercus robur). Longterm mean annual precipitations at Streletskaya, Yamskaya, and Kamennaya correspond to 580,530, and $480 \mathrm{~mm} \mathrm{yr}^{-1}$, respectively.

It is noted that although trees at the Streletskaya, Yamskaya, and Kamennaya sites were planted 55 years prior to 


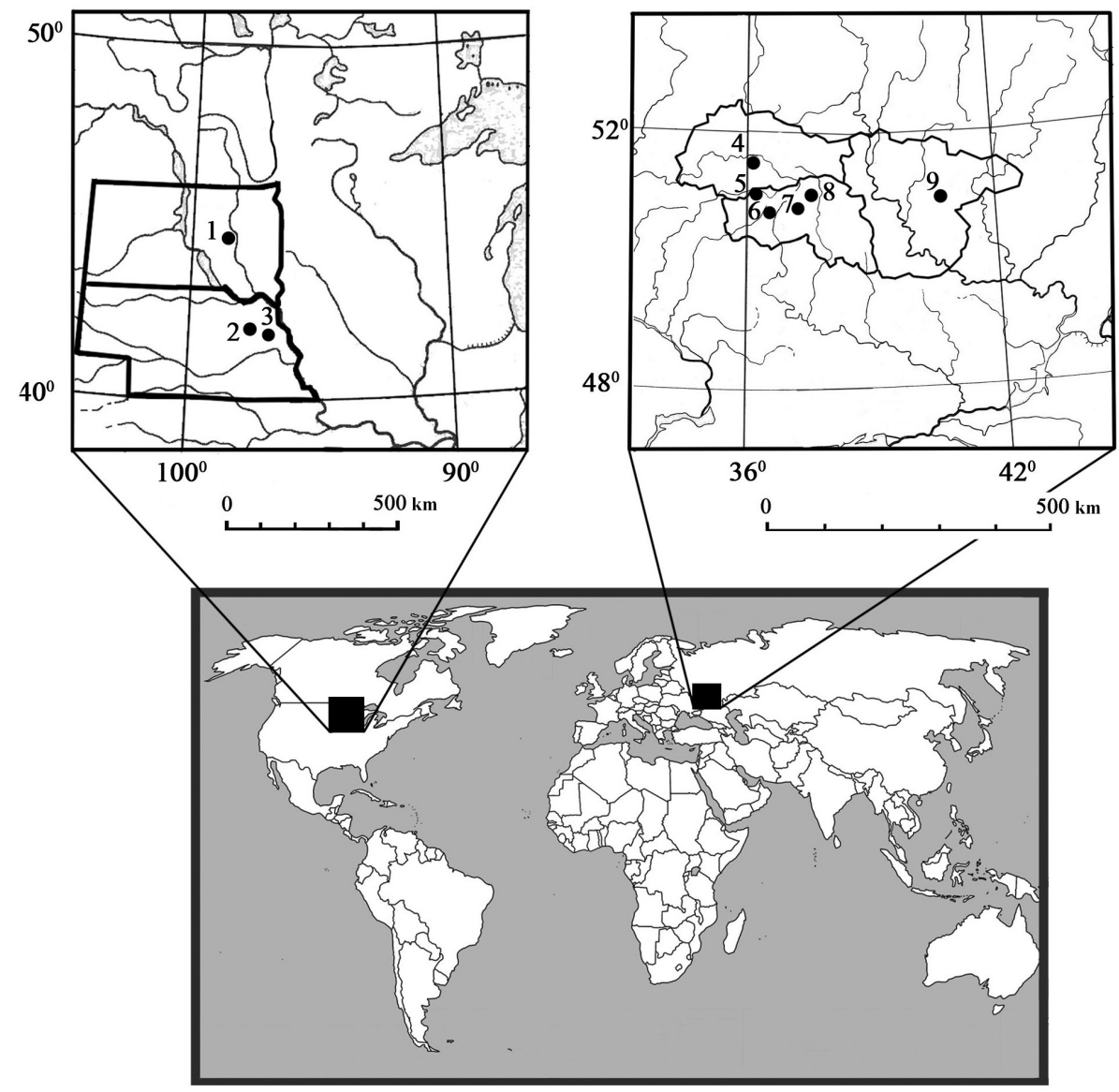

Figure 1. Geographical locations of the nine study sites within the United States ((1) Huron, (2) Norfolk, (3) Mead) and Russia ((4) Streletskaya Steppe, (5) Ivnyanskiy, (6) Prokhorovskiy, (7) Gubkinskiy, (8) Yamskaya Steppe, (9) Kamennaya Steppe). Within Russia, (5), (6), and (7) are sites with chronosequences of land use conversion, while (4), (8), and (9) are paired sites (native grasslands, annual croplands versus shelterbelts). The three sites in the United States are paired sites (afforestation vs. adjacent annual croplands).

soil sample collection, for first-order kinetics modeling purposes the tree- $\mathrm{C}$ contributions to soil $\mathrm{C}$ accrual were accounted for beginning from 50 years prior to soil sample collection. This assumption is based on a literature review by Paul et al. (2002), who suggested a lag phase of 5 years for tree-C contributions to effective start contributing to net storage of soil C. Moreover, because of the uncertainty of how close the afforested soils were to steady state and equilibrium of soil C storage, we evaluated two scenarios of firstorder kinetics modeling using Eq. (1). We assessed trajectory "A" under the premise that full steady state has been reached at the time of soil sample collection and also trajectory "B" where we assumed that the $\mathrm{C}$ storage in these afforested soils had asymptotically reached $95 \%$ of the theoretical equilibrium or ceiling capacity. We reported both trajectories and their associated $\mathrm{C}$ accretion rates $(k)$.

The rationale for implementing the $95 \%$ scenario (trajectory B) arises from the uncertainty in whether full C equilibrium has been reached. As the final phases in an asymptotic trajectory are incremental, we undertook the evaluation of a narrow but identifiable deviation below full $\mathrm{C}$ equilibrium. The choice of $95 \%$ represents that an analytical precision for quantifying soil carbon can typically be found within $5 \%$. In other words, based on a principle of detection limit in soil C measurements, $95 \%$ can be considered a minimal deviation from full equilibrium $(100 \%)$ that is already discernable but still related to the general variability of the quantification method and associated results. Hence, we took the freedom to assess this plausible range at and below full theoretical equilibrium, with the soil C storage having reached $100 \%$ or $95 \%$ of the ceiling capacity, respectively. From a broader perspective, this alternative $95 \%$ scenario also explores and represents the prospect that the soils beneath the shelterbelt could still be incrementally accruing $C$ even 55 years after tree planting. 


\subsection{Pairwise comparisons in the United States: annual croplands and afforestation}

Three field sites were studied within the Northern Great Plains of the United States near the cities of Huron (South Dakota; $44^{\circ} 15^{\prime} \mathrm{N}, 98^{\circ} 15^{\prime} \mathrm{W}$ ), Norfolk (Nebraska; $42^{\circ} 03^{\prime} \mathrm{N}$, $97^{\circ} 22^{\prime} \mathrm{W}$ ) and Mead (Nebraska; $41^{\circ} 9^{\prime} \mathrm{N}, 96^{\circ} 29^{\prime} \mathrm{W}$ ) (Fig. 1). While the focus remained on investigating the turnover rates of soil $\mathrm{C}$ as a function of land use changes, it is noted that pedogenic ages of the soils sampled in the United States were relatively shorter than the soils studied in Russian sites. This is because of the differences in geological times of parent materials exposure on the ground surface between geographic regions since the sites in the United States experienced the last glaciation (i.e., Wisconsin glaciation).

The three sites in the United States encompassed afforested areas and adjacent annual croplands, co-located in paired sites as Laganiere et al. (2010). The native vegetation at the sites had been tallgrass prairie (e.g., big bluestem $\mathrm{An}$ dropogon gerardi Vitman), which had been converted into annual croplands, and trees were subsequently planted in areas of the croplands. Afforestation took the forms of shelterbelts in Norfolk and Mead and a forest plantation in Huron. The Huron site also had an adjacent field with a representative undisturbed native prairie, which was also sampled as a reference. In contrast to the long-term croplands in Norfolk and Mead, the cropland at Huron had only 21 years since conversion from native grassland at the time of soil sample collection. Field sample collections were conducted in 2004 in Mead and in 2012 in both Norfolk and Huron. The trees had been planted 19, 35, and 70 years prior to soil sample collections in Huron, Mead, and Norfolk, respectively. Tree species included green ash (Fraxinus pennsylvanica Marshall), red cedar (Juniperus virginiana L.), and oak (Quercus macrocarpa) in Huron; red cedar, scotch pine ( $P i$ nus sylvestris L.), and cottonwood (Populus deltoides Bartram) in Mead; and Siberian elm (Ulmus pumila), red mulberry (Morus rubra), and cottonwood in Norfolk. Annual croplands were managed under conventional farming practices. Annual crop species at the study sites included wheat (Triticum aestivum L.), corn (Zea mays L.), soybean (Glycine $\max ($ L.) Merr.), and sorghum (Sorghum bicolor L. Moench). An alfalfa (Medicago sativa $\mathrm{L}$.) forage field adjacent to the shelterbelt in Norfolk was also sampled. Long-term mean annual precipitation in Huron, Norfolk, and Mead were 582, 696, and $747 \mathrm{~mm} \mathrm{yr}^{-1}$, respectively. Long-term mean annual air temperature in Huron, Norfolk, and Mead were 7.7, 9.6, and $9.9^{\circ} \mathrm{C}$, respectively. Overall, study sites had soil $\mathrm{pH}$ near neutral and textures between loamy sand to silty clay loam (Table 1).

Field methods of soil sample collections had previously been described in related reports by Chendev et al. (2015a) for the Huron and Norfolk sites as well as by Sauer et al. (2007) for Mead. Briefly, spatial grid patterns were established with composite samples $(n=4)$ collected from each
Table 1. Topsoil $\mathrm{pH}$ and textures at the nine study sites. Numerals correspond to sites as shown from west to east in Fig. 1.

\begin{tabular}{lrl}
\hline Site & Soil pH & Soil texture \\
\hline 1. Huron $^{\mathrm{a}}$ & 7.0 & sandy loam \\
2. Norfolk $^{\mathrm{a}}$ & 6.8 & loamy sand \\
3. Mead $^{\mathrm{a}}$ & 6.1 & silty clay loam \\
4. Streletskaya Steppe $^{\mathrm{b}}$ & 7.0 & loam \\
5. Ivnyanskiy $^{\mathrm{b}}$ & 7.5 & silt loam \\
6. Prokhorovskiy $^{\mathrm{b}}$ & 7.2 & loam \\
7. Gubkinskiy $^{\mathrm{b}}$ & 7.4 & clay loam \\
8. Yamskaya Steppe $^{\mathrm{b}}$ & 7.2 & loam \\
9. Kamennaya Steppe $^{\mathrm{b}}$ & 7.6 & clay loam \\
\hline
\end{tabular}

${ }^{\mathrm{a}}$ Corresponds to the cropland location within this site. ${ }^{\mathrm{b}}$ Corresponds to the native grassland location within this site.

sampling location. Total grid sampling locations were 118 at Mead, 48 at Huron, and 42 at Norfolk. Plant tissue samples of the dominant species were also collected from each study site.

Organic $\mathrm{C}$ concentration and $\delta^{13} \mathrm{C}$ isotopic composition were determined in all soil and plant samples via the dry combustion method using a Fison NA 15000 elemental analyzer (ThermoQuest Corp., Austin, TX) interfaced to an isotope-ratio mass spectrometer Delta V Advantage (Thermo Fisher Scientific, Waltham, MA). Pee Dee Belemnite was used as standard, and the analytical precision of $\delta^{13} \mathrm{C}$ measurements was $0.06 \%$. The $\delta^{13} \mathrm{C}$ isotopic ratio was expressed as

$$
\begin{aligned}
\delta^{13} \mathrm{C}(\%)= & {\left[\left({ }^{13} \mathrm{C} /{ }^{12} \mathrm{C} \text { sample }\right) /\right.} \\
& \left.\left({ }^{13} \mathrm{C} /{ }^{12} \mathrm{C} \text { standard }\right)-1\right] \times 1000 .
\end{aligned}
$$

When integrating multiple soil layers of a profile, averages of $\delta^{13} \mathrm{C}$ were weighted by the soil $\mathrm{C}$ mass density at the corresponding soil layers.

Prior to land use conversion to croplands, the native grasslands in the United States were undisturbed and dominated by plant species with $\mathrm{C}_{4}$ photosynthetic pathway, with certain mixed presence of $\mathrm{C}_{3}$ species. Based on this legacy contribution of prairie vegetation to soil $\mathrm{C}$ over the Holocene, approaches based on stable isotope signatures became feasible in the three sites in the United States. Furthermore, the ability to use a $\mathrm{C}$ stable isotope approach to partition the current soil $\mathrm{C}$ into two specific $\mathrm{C}$ pools (i.e., remaining prairie $\mathrm{C}$ and new tree $\mathrm{C}$ ) requires a constraining assumption that much of the plant residues added yearly over the annual cropping stages decomposes during the following growing season (Gregorich et al., 2017). Therefore, this premise entails that most of the $\mathrm{C}$ in crop residues enters the soil to become lost back to the atmosphere within a year and hence having near-negligible contributions to changes in both net 
$\mathrm{C}$ accrual and $\delta^{13} \mathrm{C}$ isotopic composition in the soil. This method enabled us to examine the sources of soil $\mathrm{C}$ and also derive the turnover rates of these soil $\mathrm{C}$ sources. This primarily applies because trees are $\mathrm{C}_{3}$ species. This approach assumed that the differences in ${ }^{13} \mathrm{C}$ isotopic signatures between $\mathrm{C}_{4}-\mathrm{C}_{3}$ mixed (native grassland) and $\mathrm{C}_{3}$ (trees) overrides any potential differential effect of $\mathrm{C}$ isotopic fractionations during SOM decomposition of $\mathrm{C}_{3}$ vs. $\mathrm{C}_{4}$ substrates, between aboveground and belowground plant materials (roots vs. litter) or because of SOM interactions with soil mineral surfaces (Martin et al., 1990; Hernandez-Ramirez et al., 2011). Assuming mass conservation, the measured soil $\mathrm{C}$ storages were allocated into two sources: (i) new tree $\mathrm{C}$ and (ii) remaining prairie $\mathrm{C}$ (native soil) as follows:

Tree $\mathrm{C}+$ Prairie $\mathrm{C}=1$.

Tree $\mathrm{C}=\left(\delta^{13} \mathrm{C}\right.$ afforested soil $-\delta^{13} \mathrm{C}$ native soil $) /$

$$
\left(\delta^{13} \mathrm{C} \text { tree }-\delta^{13} \mathrm{C} \text { native soil }\right) \text {. }
$$

It was inferred that all soil $\mathrm{C}$ different from the $\mathrm{C}$ identified as new "Tree C" was pre-existing soil $\mathrm{C}$ attributable to remaining "Prairie C". Likewise, we assumed that the " $\delta{ }^{13} \mathrm{C}$ native soil" was represented reasonably well by the $\delta^{13} \mathrm{C}$ measured in soil samples taken from the annually cropped fields adjacent to the afforested soils. Although they were adjacent, the sampling locations providing the $\delta^{13} \mathrm{C}$ native soil were sufficiently distant from afforested areas to preclude influence of trees on soil $\delta^{13} \mathrm{C}$. The $\delta^{13} \mathrm{C}$ native soil was $-17.3 \%$ in Huron, $-17.0 \%$ in Mead, and $-17.5 \%$ in Norfolk, which are noted to be consistent with each other as these sites share a common natural history of tallgrass prairie native vegetation. These $\delta^{13} \mathrm{C}$ native soils are also consistent with earlier measurements in prairie soils by Follett et al. (1997) and Hernandez-Ramirez et al. (2011). Furthermore, the $\delta^{13} \mathrm{C}$ measured in tree samples averaged $-27.6 \%$ in Huron, $-26.6 \%$ in Mead, and $-27.9 \%$ in Norfolk as typical isotopic compositions of $\mathrm{C}_{3}$ plant species. At the Norfolk site, tissue samples of alfalfa canopy yielded $-27.4 \%$ o. Also, in Norfolk, " $\delta{ }^{13} \mathrm{C}$ afforested soil" included all data from the soil samples taken within $10 \mathrm{~m}$ north and $10 \mathrm{~m}$ south from the center of the shelterbelt. In Huron, the $\delta^{13} \mathrm{C}$ afforested soil sample included all data from soil samples taken at least $17 \mathrm{~m}$ away from the edge between the forest plantation and the adjacent annually cropped field. In Mead, as earlier presented by Hernandez-Ramirez et al. (2011), the $\delta^{13} \mathrm{C}$ afforested soil sample included all data from soil samples collected between the existing two tree rows.

The mass densities of soil $\mathrm{C}$ derived from new tree $\mathrm{C}$ and remaining prairie $\mathrm{C}$ were calculated by multiplying wholesoil $\mathrm{C}$ storage beneath the trees with the corresponding fractions expressed in Eq. (4).

When assessing first-order kinetics modeling (Eq. 1) of soil $\mathrm{C}$ beneath trees, we assumed that the remaining prairie $\mathrm{C}$ in afforested soils at the time of soil sample collection was at steady state and had also reached new equilibria in the case of the long-term annual croplands at Norfolk and Mead. In the specific case of Huron, because the afforested soil had experienced only 2 years of annual cropping prior to tree planting, we assumed that the native grassland prior to land use conversion to annual cropping was at equilibrium and steady state.

As mentioned above, the shift from $\mathrm{C}_{4}$ - to $\mathrm{C}_{3}$-dominated vegetation in the case of the afforested soils in the United States enabled us to methodologically apportion the sources of soil $\mathrm{C}$ and to identify these direct contributions from trees to increasing soil $\mathrm{C}$ storage. In the case of the Russian sites, soil ${ }^{13} \mathrm{C}$ isotope composition does not resolve these $\mathrm{C}$ sources because of the lack of shift between $\mathrm{C}_{4}$ and $\mathrm{C}_{3}$ vegetation in the natural history of these landscapes.

Relationships between allocations of soil C sources (percent tree $\mathrm{C}$ and percent prairie $\mathrm{C}$ ) and time since tree planting (years) were examined through linear regression analyses. Likewise, a similar linear regression was developed for the proportions of remaining prairie $\mathrm{C}$ in the afforested soils relative to whole $\mathrm{C}$ present in the adjacent cropland soils. We used SigmaStat Version 4.0 software (Systat Software, San Jose, CA) and an $\alpha$ critical level of 0.05 . Where error terms $( \pm)$ are presented, they correspond to the standard error of the means.

\section{Results}

\subsection{Soil C after conversion of grasslands to cropland and then shelterbelt: Russian cases}

Long-term cultivation of native grasslands decreased soil organic C storage in a nonlinear fashion (Fig. 2). Within each of the three available land use chronosequences (i.e., each encompassing a range of different durations of cropping since land use conversion), the declining trajectory of soil $\mathrm{C}$ was represented reasonably well by first-order kinetic modeling. The RMSEn values were all lower than $4 \%$, and the $R^{2}$ values were greater than $90 \%$, which supports the suitable performance of $k$ models (Fig. 2a-c). Likewise, cross-validation results of cropland soils within the age range from 10 to 200 years further indicated the high accuracy of $k$ predictions when compared with the $1: 1$ agreement line. This was based on a non-significant $t$ test with $\beta_{1}=1$ as null hypothesis (Fig. 2d).

Within the soil layer of 0 to $30 \mathrm{~cm}$ depth in the chronosequences in Belgorod, Russia, turnover rates $(k)$ of soil C ranged from 0.0091 to $0.0183 \mathrm{yr}^{-1}$ in Gubkinskiy and Prokhorovskiy, respectively. Over the entire time spans of the three chronosequences (up to 250 years old), net soil C losses were in the relatively narrow range from $31.2 \mathrm{MgCha}^{-1}$ in Prokhorovskiy (Fig. 2a) to $36.9 \mathrm{MgCha}^{-1}$ in Gubkinskiy (Fig. 2b). Focusing on these losses of the pre-existing soil C, the estimated lapses for half of these $\mathrm{C}$ losses to take place were between 38 and 76 years after the time of land use con- 

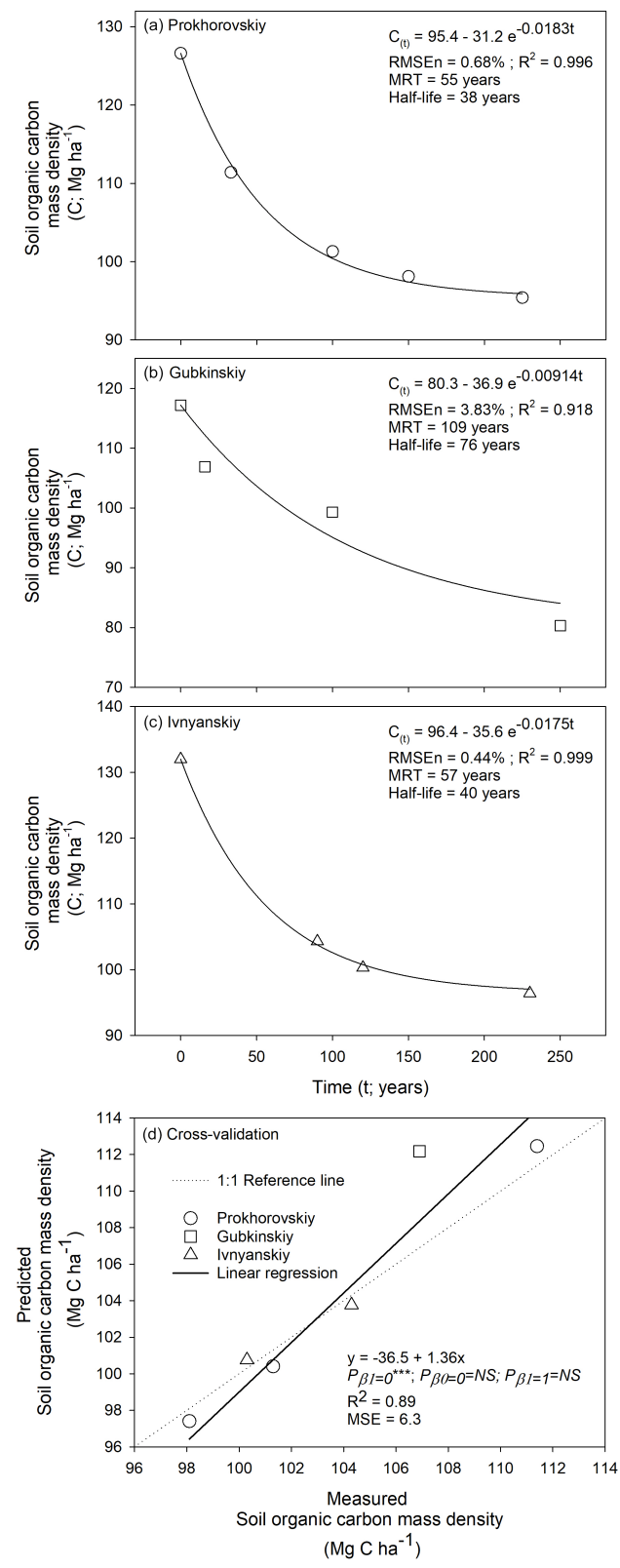

Figure 2. Land use chronosequences of soil organic carbon storage within the 0 to $30 \mathrm{~cm}$ depth increment after converting native grassland to annual croplands in Belgorod Oblast, Russia. These results showed soil $\mathrm{C}$ declines over time. (a) Prokhorovskiy, (b) Gubkinskiy, and (c) Ivnyanskiy districts. In Panels (a), (b), and (c), first-order kinetic models are described by the solid curvilinear fittings and equations in the form $\mathrm{C}_{(t)}=\mathrm{C}_{\mathrm{e}}+\left(\mathrm{C}_{o}-\mathrm{C}_{\mathrm{e}}\right) e^{-k t}$, where $\mathrm{C}_{\mathrm{e}}$ is $\mathrm{C}$ at new dynamic equilibrium (inputs = outputs), $\mathrm{C}_{o}$ is initial $\mathrm{C}$ at the time of land use conversion (time zero), and $k$ is the first-order kinetic rate constant equivalent to turnover rate. As reciprocal of $k$, MRT stands for mean residence time, while half-life equates to $\ln (2) / k$. (d) Cross-validation of first-order predicted $\mathrm{C}$ versus measured $\mathrm{C}$ encompassing the three chronosequences within the age range from 10 to 200 years. The subscripts of the $P$ values denote the null hypotheses for testing the regression coefficient $\left(\beta_{1}\right)$ and intercept $\left(\beta_{0}\right)$, where ${ }^{* * *}$ is a $p$ value of $<0.001$, and NS is not significant. First-order kinetic modeling was supported by this performance evaluation. version from native grassland to annual cropland (Fig. 2a and $b$, respectively). It is noted that new dynamic equilibria were assumed to have taken place in the oldest cropland soil within each chronosequence (i.e., >200 years) as part of first-order kinetics modeling. Furthermore, when examining the assumption of steady state (i.e., $\delta \mathrm{C} / \delta t=0$ ), soil $\mathrm{C}$ trajectories at both Prokhorovskiy and Ivnyanskiy sites showed reasonable approximations to this premise, with relatively low annual $\mathrm{C}$ losses occurring towards the end of these chronosequences. On the other hand, the Gubkinskiy site still exhibited vigorous $\mathrm{C}$ losses at the end of this chronosequence, challenging the steady-state assumption at this site. In further details, the trajectory at the Prokhorovskiy site showed estimated $\mathrm{C}$ losses of only $9.4 \mathrm{~kg} \mathrm{Cha}^{-1} \mathrm{yr}^{-1}$ during the last year of this chronosequence (Fig. 2a), which can be considered negligible and in clear agreement with a steadystate condition. Conversely, the last year of the Gubkinskiy chronosequence still showed a C loss of $34.5 \mathrm{~kg} \mathrm{C} \mathrm{ha}^{-1} \mathrm{yr}^{-1}$. It is noteworthy that these annual $\mathrm{C}$ outputs typically take the form of soil respiratory losses $\left(\mathrm{CO}_{2} \mathrm{C}\right)$ that are resultant from microbial mineralization of existing SOM. These estimations of net changes at near steady state do not account for the $\mathrm{CO}_{2}$ derived from the decomposition of recently added plant residues but just the net change in SOM C (Fig. 2a). For comparison purposes, the $k$-modeled trajectory of the Prokhorovskiy chronosequence had estimated $\mathrm{C}$ losses of $566 \mathrm{~kg} \mathrm{C} \mathrm{ha}^{-1} \mathrm{yr}^{-1}$ during the very first year after conversion from native grassland to annual cropland.

Based on the assessed pairwise comparisons, afforestation in the form of shelterbelts replenished soil $\mathrm{C}$ storage after long-term annual cropping had led to decreasing soil $\mathrm{C}$ compared with adjacent native grasslands (Table 2). Of the substantial soil $\mathrm{C}$ storage that had been depleted over time during annual cropping (i.e., $-18.9 \pm 5.3 \mathrm{Mg} \mathrm{Cha}^{-1}$ ), afforestation replenished on average $81 \%$ of these cropping-induced C losses (Table 2).

Using the insights gained from both chronosequences (Fig. 2) and paired site comparisons (Table 2), we undertook the reconstruction of soil $\mathrm{C}$ storage progression in the 0 to $30 \mathrm{~cm}$ soil layer since the land use conversion from native grassland to annual cropland and subsequently into shelterbelt (Fig. 3). After normalizing all cropland-chronosequence data (i.e., zero to one; dimensionless), turnover rates $(k)$ and first-order kinetic models of soil $\mathrm{C}$ storage were estimated (Fig. 3). This long-term $k$ model of soil $\mathrm{C}$ depletion in cropped soil had a reassuring coefficient of determination $\left(R^{2}\right)$ of $90 \%$ and a very low RMSEn of only $3.34 \%$, which collectively indicates the high precision of the $k$ model. Over 250 years of cropland chronosequence, the $\mathrm{C}$ turnover rate was quantified as $0.010 \pm 0.004 \mathrm{yr}^{-1}$, which is equivalent to an MRT of 100 years and a half-life of soil C of 69 years. This first-order trajectory of soil $\mathrm{C}$ depletion in croplands indicated that $28.9 \%$ of the initial soil $\mathrm{C}$ under native grassland was gradually lost - i.e., very likely to the atmosphere - over 250 years of annual cropping (i.e., from 1 to 0.711 , 
Table 2. Soil organic carbon storages and differences within the 0 to $30 \mathrm{~cm}$ depth increment under three land uses (i.e., native grasslands, annual croplands, and afforestation) in Russia. The nine values of soil C storage across the nine site/land uses were previously presented and discussed in Chendev et al. (2015b) and are repeated here for informing first-order kinetic modeling and estimations of $\mathrm{C}$ accretion rates when converting from annual croplands to afforestation as shown in Fig. 3. At the time of soil sample collection, the ages of the annual croplands in Streletskaya and Yamskaya were at least 140 years and at least 145 years of age in Kamennaya. In all three sites, the shelterbelts had been planted 55 years prior to soil sample collection.

\begin{tabular}{lrrrrr}
\hline $\begin{array}{l}\text { Land use or } \\
\text { descriptor }\end{array}$ & $\begin{array}{r}\text { Streletskaya } \\
\text { Steppe site, } \\
\text { Kursk }\end{array}$ & $\begin{array}{r}\text { Yamskaya } \\
\text { Steppe site, } \\
\text { Belgorod }\end{array}$ & $\begin{array}{r}\text { Kamennaya } \\
\text { Steppe site, } \\
\text { Voronezh }\end{array}$ & $\begin{array}{r}\text { Three-site } \\
\text { mean }\end{array}$ & $\begin{array}{r}\text { Standard } \\
\text { error }\end{array}$ \\
\hline Soil C mass density $\left(\mathrm{Mg} \mathrm{Cha}^{-1}\right)$ & & & & \\
\hline Native grassland (G) & 126.2 & 138.0 & 152.5 & 138.9 & 7.61 \\
Annual cropland (C) & 109.3 & 127.2 & 123.6 & 120.0 & 5.47 \\
Shelterbelt (Trees) & 126.4 & 142.1 & 125.0 & 131.2 & 5.48 \\
Net decrease G-to-C & -16.9 & -10.8 & -28.9 & -18.9 & 5.32 \\
Net increase C-to-Trees & 17.1 & 14.9 & 1.40 & 11.1 & 4.91 \\
G-to-C / C-to-Trees* & 1.01 & 1.38 & 0.05 & 0.81 & 0.40 \\
\hline
\end{tabular}

* Ratio representing the replenishing of depleted soil $\mathrm{C}$ by tree planting. These ratios were calculated as the absolute values of net increase from cropland to shelterbelt (trees) divided by net decrease from grassland to cropland.

Fig. 3). In further details, during the first year of cropping, we estimated that $0.310 \%$ of the pre-existing $\mathrm{C}$ was lost from the soil. Conversely, after 250 years, during the last year of the cropland-chronosequence trajectory, soil $\mathrm{C}$ losses were only $0.026 \%$ of the initial soil C - this is 1 order of magnitude lower than calculated for the first year of cropping. This deceleration in SOM mineralization while approaching a new equilibrium and at near steady state was captured reasonably well by first-order kinetics. Based on the soil $\mathrm{C}$ initially present under native grassland soils (threechronosequence mean $=125.3 \mathrm{Mg} \mathrm{Cha}^{-1}$, Fig. 2), these values of $0.31 \%$ and $0.026 \%$ were equivalent to $\mathrm{C}$ outputs of 392 and $33 \mathrm{~kg} \mathrm{Cha}^{-1} \mathrm{yr}^{-1}$, respectively.

We projected two potential trajectories (A and B) of how afforested soils can restore soil C storage in cropland soils over 5 decades (Fig. 3). After replenishing $81 \%$ of the C lost during long-term annual cropping, the shelterbelts had $94.5 \%$ of the initial $\mathrm{C}$ of the native grassland (i.e., $0.81 \times$ $0.289+0.711=0.945$, Table 2). Trajectory A was estimated on the basis that afforested soils fully reached a new steady state and equilibrium of soil $\mathrm{C}$ storage with first-order modeling. This trajectory showed a steep increase in soil C storage over the first decade of tree planting. In fact, the $\mathrm{C}$ accretion rate for trajectory A was $0.119 \mathrm{yr}^{-1}$, which suggests a potential for high soil $\mathrm{C}$ accretion under fast $\mathrm{C}$ cycling with afforestation. Because the soils beneath the shelterbelt can still be actively accruing $\mathrm{C}$ even 55 years after tree planting, we also developed trajectory $\mathrm{B}$, which targets a scenario where soil $\mathrm{C}$ storage reached $95 \%$ of a theoretical equilibrium (Fig. 3). For this trajectory, the resultant $\mathrm{C}$ accretion rate was $0.0334 \mathrm{yr}^{-1}$, which corresponds to a modeled MRT of 30 years. When focusing on these progressive gains of new soil $\mathrm{C}$ under trajectory $\mathrm{B}$, the estimated time for half of this soil $\mathrm{C}$ portion to enter the soil was 21 years. Over the two last decades of this progression, the soil $\mathrm{C}$ accretion starts to gradually become asymptotic. During the first year of trajectory $\mathrm{B}$, the net accrual of soil $\mathrm{C}$ was equivalent to $0.88 \%$ of the soil $\mathrm{C}$ initially present in the native grasslands (Fig. 3). Conversely, during the last year of trajectory $\mathrm{B}$, soil $\mathrm{C}$ accretion corresponded to only $0.17 \%$. Based on the soil $\mathrm{C}$ initially present under native grassland soils (three-chronosequence mean $=125.3 \mathrm{Mg} \mathrm{Cha}^{-1}$, Fig. 2), these $0.88 \%$ and $0.017 \%$ values were equivalent to sizable 1.10 and $0.21 \mathrm{MgC} \mathrm{ha}^{-1} \mathrm{yr}^{-1}$, respectively. It is noted that in each of the two afforestation trajectories of soil $\mathrm{C}$ accretion (A and $\mathrm{B}$ ), the annual contributions of afforestation to net accrual of soil $\mathrm{C}$ began from the soil $\mathrm{C}$ storage estimated by the $k$-modeled cropland trajectory 50 years prior to soil sample collection (i.e., 0.728, Fig. 3). This is because we had assumed a lag phase of 5 years as noted above, and tree planting was 55 years prior to soil sample collection.

Based on the assembled $k$ models of cropland $\mathrm{C}$ turnover and simultaneous tree-C accretion (Fig. 3), of the wholesoil $\mathrm{C}$ measured beneath the trees at the time of soil sample collection (Table 2), $25 \%$ was estimated to be derived directly from tree-C contributions (i.e., (0.945-0.711) / 0.945). This can indicate that although tree-C contributions were substantial, the majority of the $\mathrm{C}$ stored in these steppe soils still originated from the initial native grassland before land use conversion to annual croplands.

\subsection{Sources and turnover of soil C in afforested croplands: United States cases}

Larger accumulation of soil $\mathrm{C}$ was consistently found beneath trees relative to the adjacent annual croplands in all three study sites within the Northern Great Plains of the United States. At the shelterbelts in Norfolk (Fig. 4e) and 


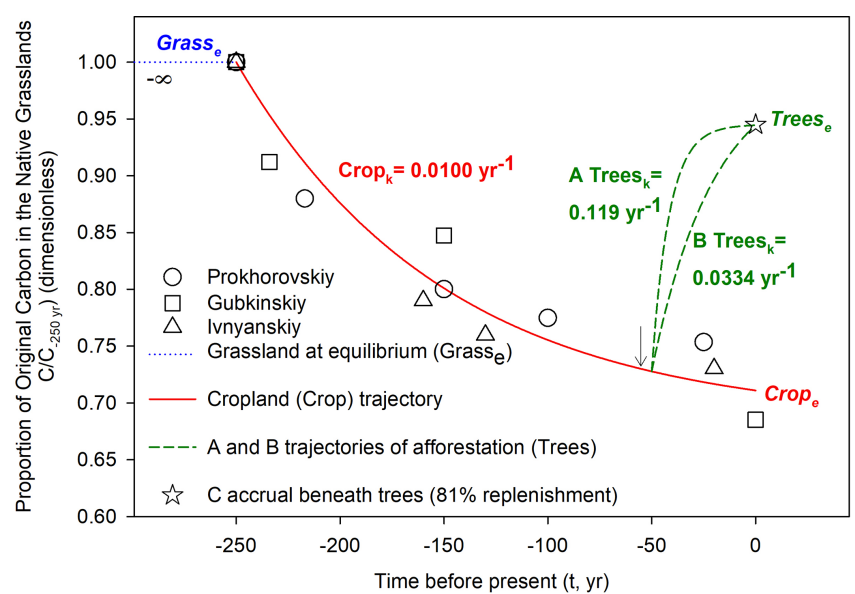

Figure 3. Reconstruction of soil organic carbon storage within the 0 to $30 \mathrm{~cm}$ depth increment following land use conversions from native grassland to annual cropland and subsequently into afforestation with shelterbelts in Russia. This assemblage assumed that native grasslands were at dynamic equilibrium and steady state prior to conversion to annual croplands. Likewise, nonlinear $k$ estimates of turnover rates in croplands and accretion rates under afforestation also required the assumptions of reaching new dynamic equilibria and steady state at zero year (i.e., time of soil sample collection). The cropland trajectory of soil $\mathrm{C}$ over time was derived from chronosequence data presented in Fig. 2a, b, and c. The soil C accrual beneath trees at time zero (open star) was estimated from measured data presented in Table 2 (i.e., of the soil $\mathrm{C}$ that had been depleted by cropping, afforestation replenished $81 \%$, based on three-site mean). Note that although trees were planted on year -55 (vertical arrow $\downarrow$ ), tree-C contributions to soil $\mathrm{C}$ accrual were accounted for starting from year -50 based on a literature review by Paul et al. (2002) that suggested a lag phase of 5 years. The trajectory "B Trees" (dashed red line with $k=0.0334 \mathrm{yr}^{-1}$ ) assumed that the soil C storage had asymptotically reached $95 \%$ of a theoretical equilibrium (i.e., "Trees" $\left.\mathrm{e}_{\mathrm{e}} / 0.95\right)$. First-order kinetic modeling was used to derive these three nonlinear trajectories of soil C (Eq. 1). With the aim of integrating information from the three available chronosequences (Fig. 2), all soil C storage data were normalized (i.e., zero to one) and presented here as fractions of $\mathrm{C}$ storage at time of conversion from native grassland to annual cropland (shown as -250 years before time of soil sample collections).

Mead (data not shown) as well as the forest plantation in Huron (Fig. 4f), the stable isotope approach followed by mass balance effectively allocated and quantified the treederived soil $\mathrm{C}$, in particular within the 0 to $15 \mathrm{~cm}$ soil depth increment (Table 3).

At the Norfolk site, soils collected from the 0 to $15 \mathrm{~cm}$ depth increment beneath the trees (i.e., within $10 \mathrm{~m}$ distance from the center of the shelterbelt) resulted in more than double of the $\mathrm{C}$ mass density found in the annually cropped topsoils that were located farthest from the trees (28 vs. $13 \mathrm{MgCha}^{-1}$; Table 3, Fig. 4a). Concurrently, when comparing the same surface layer and spatial sampling locations, soil $\delta^{13} \mathrm{C}$ sharply shifted from a considerably depleted
$-25.7 \pm 0.1 \%$ o beneath the trees to $-17.5 \pm 0.1 \%$ in the cropped soils north from the shelterbelt (Fig. 4c). As a result, a significant $79 \%$ of the soil $\mathrm{C}$ storage measured beneath the trees at the time of sample collection was attributed to treeC contributions (Table 3 ). This translated into a substantial magnitude of $22 \mathrm{MgC} \mathrm{ha}^{-1}$ being derived specifically from tree biomass (Table 3). Moreover, as stated above (Sect. 2.3), the rest of the soil $\mathrm{C}$ was attributed to remaining prairie $\mathrm{C}$. The existing soil $\mathrm{C}$ beneath trees in the Norfolk shelterbelt allotted to remaining prairie $\mathrm{C}$ was only $45.5 \pm 0.3 \%$ of the whole-soil $\mathrm{C}$ typically found in the adjacent annual crop field (Table 3). This indicated that $54.5 \%$ of the soil $\mathrm{C}$ (equivalent to $13.0-5.9=7.1 \pm 0.4 \mathrm{Mg} \mathrm{Cha}^{-1}$, Table 3) that existed under the long-term annual cropland (i.e., assumed to be at steady state) prior to tree planting has been lost from the topsoil over the 70 years of afforestation at Norfolk. This net decline in remaining prairie $\mathrm{C}$ is attributable to $\mathrm{CO}_{2}$ respiratory losses from enhanced biological activity beneath the trees that gradually accessed, mobilized, cycled and partly mineralized this legacy prairie-C pool. These results indicated that the turnover of remaining prairie $\mathrm{C}$ in afforested soils can be even faster than in open cropland fields.

Because the crop field south from the shelterbelt in Norfolk was dedicated to perennial cropping of alfalfa forage - a $\mathrm{C}_{3}$ species - we undertook a mass balance to distinguish and allocate the $\mathrm{C}$ sources as alfalfa $\mathrm{C}$ vs. remaining prairie $\mathrm{C}$, with a similar approach as in the afforested areas (i.e., Eqs. 4 and 5). Within the 0 to $15 \mathrm{~cm}$ depth increment, soil $\mathrm{C}$ storage under alfalfa (i.e., $13.1 \pm 1.0 \mathrm{MgC} \mathrm{ha}^{-1}$ ) was the same as in the annual cropland on the north side of the shelterbelt (Fig. 4a, Table 3). However, the soil $\delta^{13} \mathrm{C}$ shifted to $-21.6 \pm 0.4 \%$, which resulted in a $41.2 \pm 0.4 \%$ replacement of the whole-soil $\mathrm{C}$ storage being derived specifically from recent contributions of alfalfa $\mathrm{C}$ in this perennial forage field.

Similar to Norfolk, the shelterbelt at Mead also showed a major contribution of afforestation to whole-soil C storage between tree rows in the 0 to $15 \mathrm{~cm}$ depth increment (i.e., $17 \mathrm{MgC} \mathrm{ha}^{-1}$, Table 3), which corresponded to $37 \%$ of the whole-soil C. It is noted that although the magnitude of original prairie $\mathrm{C}$ lost after 35 years of afforestation at Mead (i.e., 36.2-29.3 $=6.9 \pm 0.7 \mathrm{MgC} \mathrm{ha}^{-1}$, Table 3 ) was comparable to Norfolk, the proportion of this original prairie $\mathrm{C}$ lost from afforested soils in Mead was much smaller with only $19 \%$ (i.e., 100-80.9, Table 3). This can indicate that the net changes in whole-soil $\mathrm{C}$ storage under afforestation (i.e., simultaneously encompassing the noted prairie-C losses and the asymmetrically larger tree-C gains) did not follow a fixed proportionality to the initial prairie $\mathrm{C}$.

At the 19-year-old forest plantation at Huron, trees also increased soil $\mathrm{C}$ storage while decreasing the $\delta^{13} \mathrm{C}$ signature, in particular in the 0 to $15 \mathrm{~cm}$ depth increment (Fig. $4 \mathrm{~b}$, d). When contrasting the afforested soils collected at least $17 \mathrm{~m}$ away from the plantation boundary vs. topsoils taken within the adjacent cropland from the sampling locations 


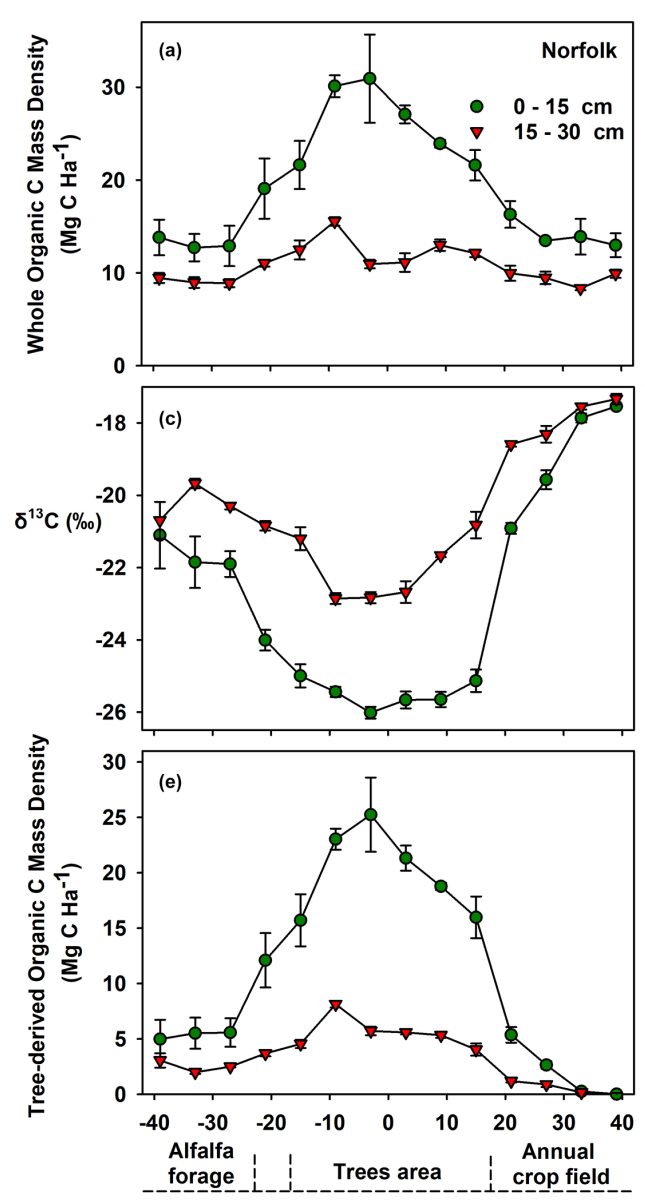

Transect (m, South to North)
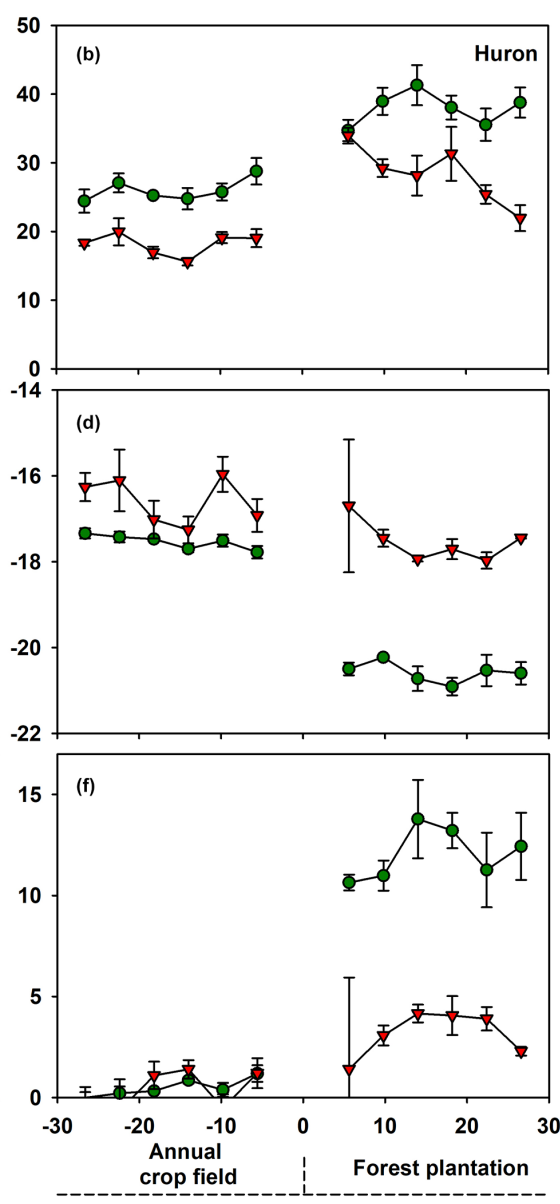

Transect (m, South to North)

Figure 4. (a, b) Soil organic carbon mass storage, $(\mathbf{c}, \mathbf{d})$ stable isotope ratios of organic $\mathrm{C}\left(\delta^{13} \mathrm{C}\right)$ and $(\mathbf{e}$, f) organic $\mathrm{C}$ mass derived from $\mathrm{C}_{3}$ plants across transects at Norfolk shelterbelt (a, c, e) and Huron forest plantation (b, d, f) for the 0 to 15 and 15 to $30 \mathrm{~cm}$ soil depth increments. Adjacent cropped fields were also included. Within the afforested areas in panels (e) and (f), the reported organic $\mathrm{C}$ masses are primarily attributed to direct tree contributions. Contributions of tree-C to soil $\mathrm{C}$ storage were clearly discernable within the 0 to $15 \mathrm{~cm}$ depth increment. Note the difference in vertical $y$ scales across panels. Error bars are standard error of the means, with sample sizes of 4 for Huron and 3 for Norfolk.

Table 3. Soil organic carbon storage within the 0 to $15 \mathrm{~cm}$ depth increment contrasting annual croplands and afforestation in the United States. Sources of soil C storage beneath the trees were allocated as tree C versus remaining prairie C using Eqs. (4) and (5) and associated assumptions. Error bars are standard error of the means.

\begin{tabular}{|c|c|c|c|c|c|c|c|c|}
\hline \multirow[t]{2}{*}{ Site } & \multirow[t]{2}{*}{$\begin{array}{r}\text { Tree age } \\
(\mathrm{yr})\end{array}$} & \multicolumn{2}{|c|}{$\begin{array}{l}\text { Whole-soil C } \\
\text { mass density }\end{array}$} & \multicolumn{2}{|c|}{$\begin{array}{c}\text { Tree } \mathrm{C} \text { to } \\
\text { contribution } \\
\text { soil C }\end{array}$} & \multicolumn{2}{|c|}{$\begin{array}{c}\text { Remaining } \\
\text { prairie C }\end{array}$} & \multirow{2}{*}{$\begin{array}{r}\text { Remaining } \\
\text { prairie C/ } \\
\text { whole C in } \\
\text { cropland }^{*} \\
\begin{array}{r}\text { Proportion } \\
(\%)\end{array}\end{array}$} \\
\hline & & $\begin{array}{r}\text { Annual } \\
\text { cropland } \\
\left(\mathrm{MgCha}^{-1}\right)\end{array}$ & $\begin{array}{r}\text { Beneath } \\
\text { trees } \\
\left(\mathrm{MgCha}^{-1}\right)\end{array}$ & $\begin{array}{r}\text { Mass } \\
\text { density } \\
\left(\mathrm{Mg} \mathrm{Cha}^{-1}\right)\end{array}$ & $\begin{array}{r}\text { Proportion } \\
(\%)\end{array}$ & $\begin{array}{r}\text { Mass } \\
\text { density } \\
\left(\mathrm{MgCha}^{-1}\right)\end{array}$ & $\begin{array}{r}\text { Proportion } \\
(\%)\end{array}$ & \\
\hline Mead, Nebraska & 35 & $36.2 \pm 0.4$ & $46.7 \pm 1.5$ & $17.4 \pm 1.2$ & $37.2 \pm 1.8$ & $29.3 \pm 1.9$ & $62.8 \pm 1.8$ & $80.9 \pm 3.6$ \\
\hline Norfolk, Nebraska & 70 & $13.0 \pm 1.3$ & $28.0 \pm 1.4$ & $22.1 \pm 1.1$ & $78.9 \pm 1.0$ & $5.90 \pm 0.42$ & $21.1 \pm 1.0$ & $45.5 \pm 0.3$ \\
\hline
\end{tabular}

* This ratio represents the proportion of remaining prairie $\mathrm{C}$ relative to whole-soil C in annual cropland. The magnitudes of both "remaining prairie C" and "whole-soil C in annual cropland" are shown in other columns of this same table. It is noted that balance (e.g., in Mead, $100-81=19$ ) represents the proportion of prairie C lost in afforested soils since tree planting. 
that were farthest removed from the trees, $\delta^{13} \mathrm{C}$ changed from $-20.7 \pm 0.2 \%$ to $-17.3 \pm 0.1 \%$, respectively. Although trees were much younger in Huron than in Mead and Norfolk, a considerable magnitude of tree $\mathrm{C}$ was found (i.e., $12 \mathrm{Mg} \mathrm{Cha}^{-1}$, Table 3). This indicated that direct tree contributions to soil $\mathrm{C}$ storage can take place rather quickly, within a few decades following afforestation. However, the changes in the remaining prairie- $\mathrm{C}$ pool beneath the trees at Huron apparently differed from what was found in both Mead and Norfolk. While soils beneath trees at both Mead and Norfolk showed declines in remaining prairie $\mathrm{C}$ relative to whole-soil $\mathrm{C}$ stored in open cropland fields at the time of sample collection, the afforested soil at Huron showed no change in the magnitude of remaining prairie $\mathrm{C}$ in the 0 to $15 \mathrm{~cm}$ depth increment. In fact, it is striking how similar the whole $\mathrm{C}$ in the cropped soil $\left(25.6 \pm 0.7 \mathrm{MgCha}^{-1}\right)$ was to the $\mathrm{C}$ allocated to the remaining prairie- $\mathrm{C}$ pool beneath the trees $\left(25.3 \pm 0.7 \mathrm{MgCha}^{-1}\right.$, Table 3$)$. What is more, the soils sampled from the adjacent native grassland within the Huron site also returned a very consistent magnitude of soil $\mathrm{C}$ storage, with $25.4 \pm 1.9 \mathrm{Mg} \mathrm{Cha}^{-1}$ ( $n=3$; data not shown). Provided with the uncertainty of field sampling, this evidence strongly indicated that all or nearly all the original prairie $\mathrm{C}$ was retained and still present in the Huron soils under both annual cropping and afforestation (Table 3). Likewise, when examining the 0 to $30 \mathrm{~cm}$ soil depth increment at Huron (i.e., aggregating the two sampled soil layers shown in Fig. 4b), we further corroborated this similarity in soil $\mathrm{C}$ storage between native grassland and annual cropland $(45.4 \pm 1.0$ vs. $44.2 \pm 1.1 \mathrm{Mg} \mathrm{Cha}^{-1}$, respectively; data not shown).

Significant regressions revealed the consistent dependency of $\mathrm{C}$ source allocations on time since tree planting (Fig. 5). Over time following afforestation, tree-C source increased linearly from an assumed null contribution at planting to become $79 \%$ of the whole-soil $\mathrm{C}$ after 70 years of tree planting in Norfolk $\left(R^{2}=0.95\right.$, Fig. 5a). We also evaluated changes over time for the remaining prairie $\mathrm{C}$ in afforested soils relative to the corresponding adjacent croplands within each study site. Linearity of these prairie-C proportions as a function of time was also observed when encompassing the three study sites $\left(R^{2}=0.999\right.$, Fig. $\left.5 b\right)$. As described above, the more recently afforested soils at the Huron site kept the entire prairie $\mathrm{C}$, while the oldest afforested soils at the Norfolk site retained less than half of the whole-soil $\mathrm{C}$ present in the adjacent annual croplands (45.5\%).

We focused on estimating the turnover rates of soil $\mathrm{C}$ mass density derived directly from tree-C sources while encompassing the range of conditions in the three studies. As most of the beneficial effects of tree planting across the sites in the United States were detected in the 0 to $15 \mathrm{~cm}$ soil depth increment, further examination of accretion rates of soil C storage focused on this specific topsoil layer. Upon assembling the magnitudes of tree-C contributions over time since afforestation, unified first-order kinetics modeling converged and emerged robustly $\left(R^{2}=0.997\right.$, Fig. 6). The $k$
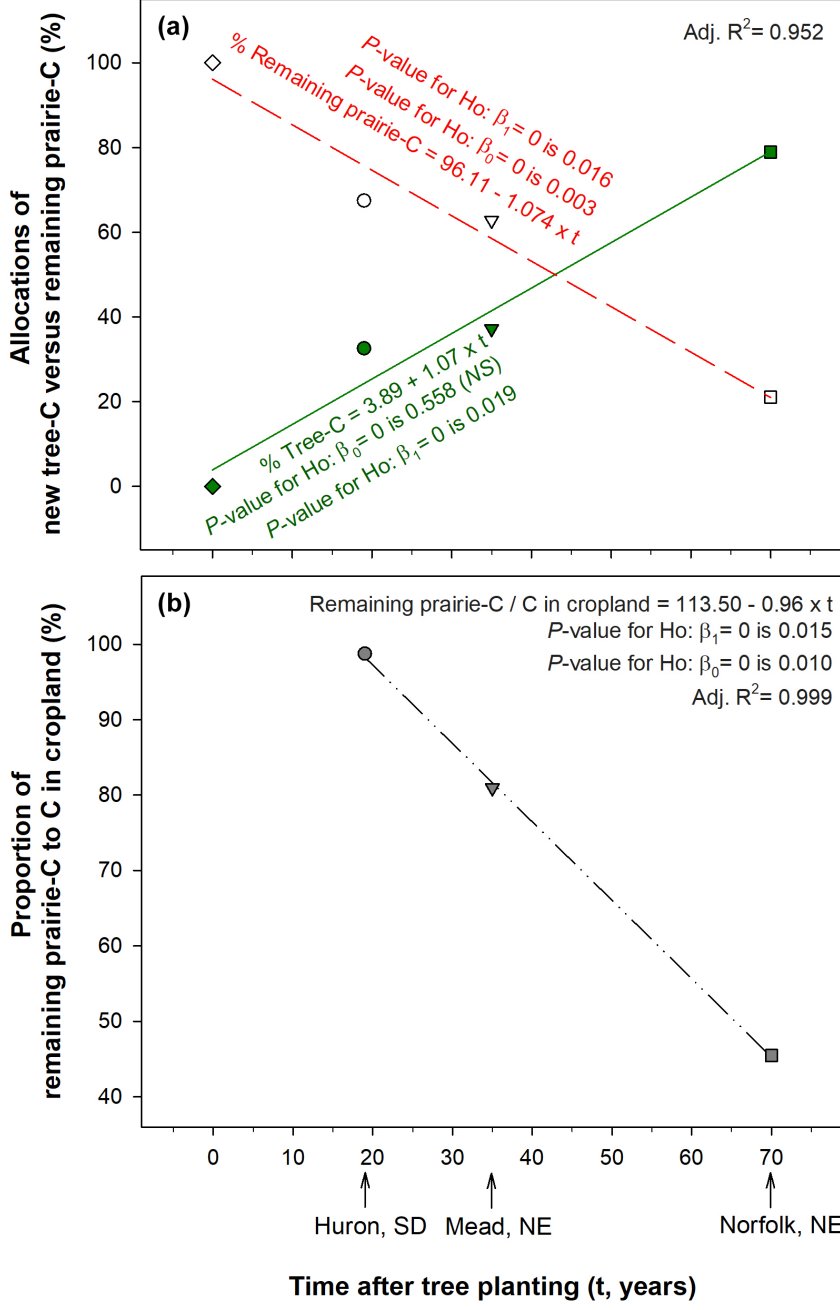

Figure 5. Proportions of soil organic carbon within 0 to $15 \mathrm{~cm}$ depth increment (a) from tree $\mathrm{C}$ versus remaining prairie $\mathrm{C}$ relative to whole-soil $\mathrm{C}$ stored directly beneath trees and (b) remaining prairie $\mathrm{C}$ in afforested soils relative to whole-soil $\mathrm{C}$ in the adjacent croplands. It was inferred that all soil $\mathrm{C}$ different from new tree $\mathrm{C}$ was pre-existing soil $\mathrm{C}$ attributable to remaining prairie C. (a) Mead data were recalculated from Hernandez-Ramirez et al. (2011) as compiled in Table 3 . The tree-C source increased to become $79 \%$ of the whole-soil $\mathrm{C}$ over 70 years after tree planting. (b) The proportion of prairie-derived $\mathrm{C}$ beneath trees declined over time to become less than half $(45 \%)$ of the whole-soil $\mathrm{C}$ in the adjacent annual croplands, which were assumed to be at steady state.

rate constant of $0.0552 \mathrm{yr}^{-1}$ corresponds to a half-life of 12.6 years, which indicates that more than half of the accrual tree $\mathrm{C}$ occurred within less than 2 decades (when accounting for a lag phase of 5 years following tree planting) (Fig. 6). This further substantiated the rapid contributions of afforestation to increase soil $\mathrm{C}$ storage quickly until reaching a new dynamic equilibrium. This generalized relationship enabled projecting tree-C accruals in afforested soils within the assessed time range of 70 years. We further im- 


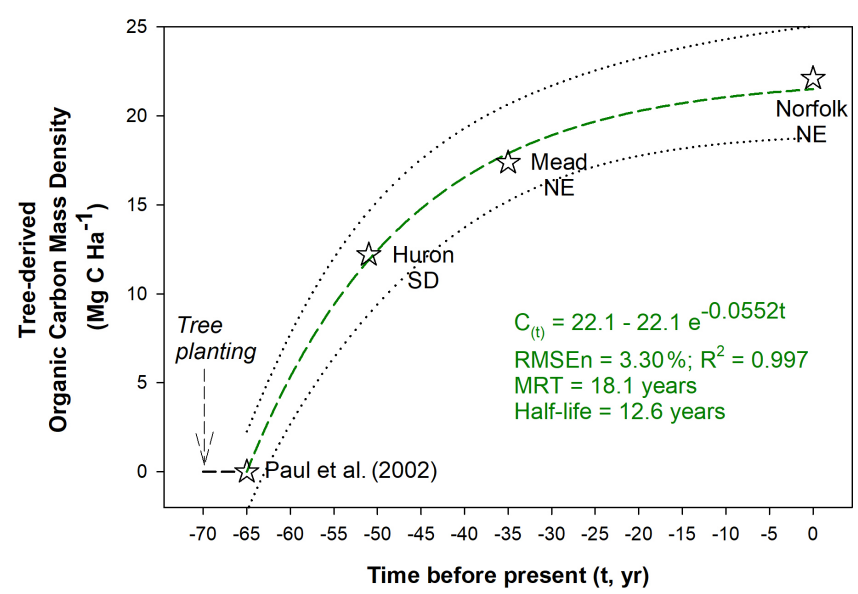

Figure 6. Reconstruction of soil organic carbon storage within the 0 to $15 \mathrm{~cm}$ depth increment following land use conversion from annual cropland to afforestation in the United States. The arrow indicates the time of tree planting ( -70 years). Based on a literature review by Paul et al. (2002), we included a lag phase of 5 years following tree planting. Huron and Norfolk data were derived from results presented in Fig. 4. Mead data were recalculated from HernandezRamirez et al. (2011) as compiled in Table 3. This assemblage supports that afforested soils were approaching steady state at nearly 70 years after tree planting, as required for first-order kinetic modeling. The first-order kinetic model (Eq. 1) is depicted by the solid curvilinear fitting, where $k$ is the first-order kinetic rate constant equivalent to accretion rate under afforestation, and MRT stands for mean residence time. Normalized root-mean-square error (RMSEn) and coefficient of determination $\left(R^{2}\right)$ for the $k$ model are also provided. The $95 \%$ prediction bands of this $k$ model are provided as dotted lines. This nonlinear trajectory describes and highlights the contribution of trees to soil $\mathrm{C}$ accrual.

plemented this robust $k$ progression to simultaneously depict the gains in tree $\mathrm{C}$ while also representing the declines in prairie $\mathrm{C}$ in afforested soils for each study site separately (Fig. 7). This approach accounts for the $\mathrm{C}$ that is being lost from net mineralization of pre-existing $\mathrm{C}$ in the remaining prairie SOM (Fig. 7). It was noticeable that the afforested soils at Mead showed faster turnover rate of the remaining prairie $\mathrm{C}$ than the other two sites by approximately two-fold. The $k$ rate constant of net mineralization of prairie $\mathrm{C}$ beneath trees at Mead was $0.145 \mathrm{yr}^{-1}$ (Fig. 7b), which corresponded to an MRT of about 7 years. This implies that the average time for prairie $\mathrm{C}$ to be lost from Mead afforested soils was well within 1 decade, whereas prairie $\mathrm{C}$ in afforested soils in Huron and Norfolk showed longer residence times by about double.
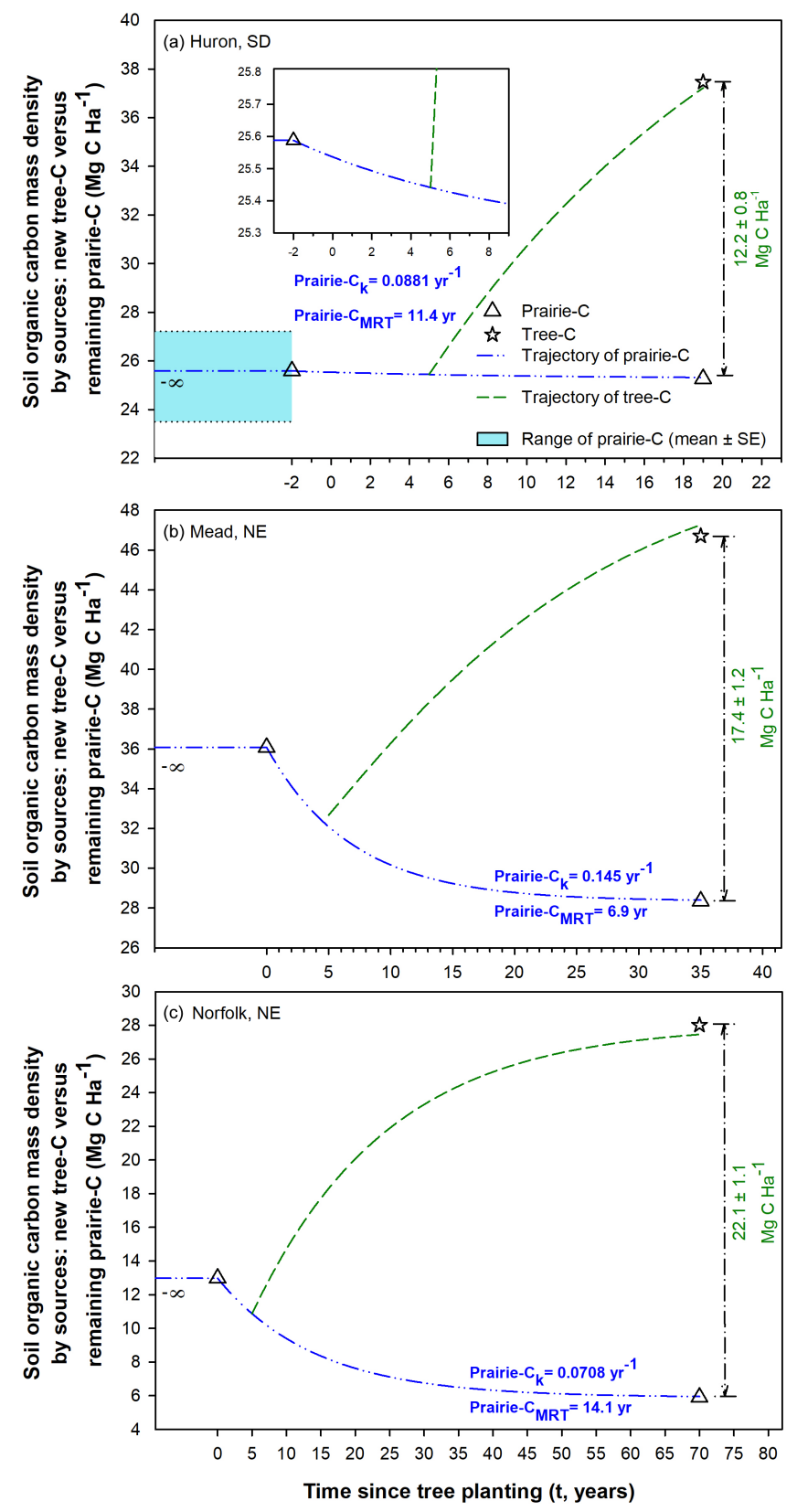

Figure 7. Net carbon accretion in afforested soils caused by simultaneous $\mathrm{C}$ gains from substantial tree-C contributions and smaller $\mathrm{C}$ losses from mineralization of remaining prairie $\mathrm{C}$. It was inferred that all soil $\mathrm{C}$ different from new tree $\mathrm{C}$ was pre-existing soil $\mathrm{C}$ attributable to remaining prairie $\mathrm{C}$. Time of tree planting was set at the year zero. Based on a literature review by Paul et al. (2002), we included a lag phase of 5 years following tree planting. The accretion trajectories of tree $\mathrm{C}$ presented within each panel were projected using the unified first-order model developed in Fig. 6. The magnitude of tree-C gains as well as the turnover rates $(k)$ and mean residence time (MRT) of prairie-C trajectories are provided within each panel. The Huron site (a) had an adjacent native grassland available, which here is provided as a reference and plotted prior to the time of conversion into annual cropland. Note the different $x$ and $y$ scales across panels. 


\section{Discussion}

\subsection{Carbon contributions from trees to SOM sequestration}

Planting trees in croplands creates substantial sinks of atmospheric C in the soil profile (Sauer et al., 2007; Khaleel et al., 2020; Zhang et al., 2020). Current knowledge of this important benefit of afforestation has been deepened and reinforced in earlier literature (Post and Kwon, 2000; HernandezRamirez et al., 2011; Chendev et al., 2015b). It is noticeable that having long-term annual croplands as the land use system prior to establishing trees particularly enlarges the soil C sink and replenishment caused by afforestation (Guo and Gifford, 2002; Laganiere et al., 2010; Sauer et al., 2012). Overall results indicate that across tree species and local edaphic-climatic conditions at the studied sites, the massive tree-C contributions through decaying roots and litter ( $\mathrm{Li}$ et al., 2012; Amadi et al., 2016) can saturate the soil with C substrates in surplus to the capacity of microbial decomposition (Li et al., 2018; Deng et al., 2014), which collectively incline the $\mathrm{C}$ balance towards net $\mathrm{C}$ accrual (Hernandez-Ramirez et al., 2011). Our quantification of these tree-biomass-C contributions to newly accrued soil $\mathrm{C}$ further expand this growing body of knowledge. The proportion of new soil $\mathrm{C}$ originated from tree biomass was shown to increase significantly with time (Fig. 5a).

By contrast to afforestation, long-term annual cropping implies recurrent soil mixing, disruption of any pre-existing vertical stratification, microclimate fluctuation, and exposure of SOM to decomposition, which collectively shift the C balance and predispose towards depletion of soil C (Post and Kwon, 2000; Hernandez-Ramirez et al., 2009; Curtin et al., 2014). In addition to this disturbance and exposure of SOM to decomposition, low $\mathrm{C}$ inputs and high $\mathrm{C}$ removals via harvest are also characteristic of conventional annual cropping systems. Moreover, results indicated that $\mathrm{C}$ from crop residues was largely lost back to the atmosphere every year with no significant net contribution to the soil organic $\mathrm{C}$ pools in the long term (Figs. 2, 3). A reduction of $\mathrm{C}$ inputs in croplands once the native vegetation (roots and aboveground biomass) have been removed (Hu et al., 2013) is also typically followed by alterations in soil physical properties such as decreases in porosity and gas exchange which can become detrimental to plant primary productivity and soil biology (Kiani et al., 2017).

Our study explicitly examined and quantified for the first time in literature the losses of remaining prairie $\mathrm{C}$ directly beneath trees across afforested soils (Figs. 3, 5b, 7). This analysis showed that under afforestation soil $\mathrm{C}$ remaining from original native grasslands continues to be lost from the profile, likely via microbial mineralization (Figs. 3, 7). It is noted that the accretion of recently added tree $\mathrm{C}$ is much faster than these observed losses of remaining prairie $\mathrm{C}$ beneath trees as the recently added plant $C$ is considered relatively more la- bile than prairie $\mathrm{C}$. The noted decline in remaining prairie $\mathrm{C}$ beneath young afforestation agrees well with a decomposition of SOM in the early stage of tree growth as previously deliberated by Paul et al. (2002), Garten (2002), and Xiong et al. (2020). At the Norfolk site, tree-C contributions effectively replenished and greatly surpassed the gradual losses of remaining prairie $\mathrm{C}$ in the soil (Fig. 7c). In the case of the Huron site, afforestation conserved the initial prairie $\mathrm{C}$ while also contributing directly to additional tree $\mathrm{C}$ accrued in an overall increasing SOM pool (Fig. 7a)

It is noted that although the three US sites (Norfolk, Huron, and Mead) shared a common trajectory of tree $\mathrm{C}$ accretion with time (Figs. 5, 6), their $k$ turnover rates of remaining prairie $\mathrm{C}$ differed (Fig. 7). These apparent divergences are potentially attributable to differences in temperature and moisture regimes across the region. In further details, in the case of accretion of tree $\mathrm{C}$ in afforested soils, this response to land use change seems governed mostly by the change into tree vegetation and the duration of afforestation; therefore, it became feasible for us to establish a unified, robust $k$ model across a range of afforestation ages (Fig. 6). Conversely, loss rates of remaining prairie $\mathrm{C}$ in afforested soils appeared to be mostly contextual and even site specific, likely as a function of local climatic conditions (Chendev et al., 2014, 2015b). Relative to both Norfolk and Huron (Fig. 7), warmer/wetter conditions in Mead could have led to the faster $\mathrm{C}$ turnover rate and mineralization of the remaining prairie $\mathrm{C}$ in these afforested soils (Fig. 7b). Overall, these results exemplify how analyzing the compartments of soil $\mathrm{C}$ turnover - evaluating separately tree-C contributions and remaining prairie $\mathrm{C}$ instead of studying only the whole-soil $\mathrm{C}$ - can provide further insights into SOM dynamics following land use conversions. Future research could address the potential existence of underlying thresholds of heat and moisture availabilities that are conducive to retain and converse pre-existing prairie $\mathrm{C}$ in afforested soils while simultaneously enabling soil $\mathrm{C}$ accretion directly from new tree-C contributions. Likewise, SOM fractionation approaches offer excellent avenues for further unraveling the stabilization mechanisms of $\mathrm{C}$ in the soil.

Based on the kinetics-modeled reconstruction of soil $\mathrm{C}$ storage over time in the Russian land use chronosequences (i.e., encompassing a range of different ages since conversion to annual cropping), over the 55 years that elapsed since tree planting until soil sample collection, the remaining soil $\mathrm{C}$ from the original native grassland was shown to be lost continually (Fig. 3). Our turnover estimations using kinetics modeling suggested that only $1.7 \%$ of the initial grassland $\mathrm{C}$ was lost over these 55 years following shelterbelt afforestation (Fig. 3). Based on these results from the Russian chronosequences, the relatively small grassland-C loss is in part because soil $\mathrm{C}$ had been depleted over nearly two centuries of annual cropping prior to tree planting. Nevertheless, mycorrhizae activity in afforested soils can preferentially access and utilize remaining grassland $\mathrm{C}$ beneath trees (Mellor et al., 2013). Hence, this biological effect could contribute 
to gradual decreases in remaining grassland $\mathrm{C}$ in afforested soils.

Chendev et al. $(2014,2015 b)$ further addressed differences in soil $\mathrm{C}$ accrual across afforested sites in Russia and the United States, also attributing them primarily to differences in moisture regimes. Within each geographic region as well as in the collective of both countries, they explained that cooler-moister conditions led to increases in overall soil $\mathrm{C}$ accrual beneath trees. This postulate is clearly in line with earlier results by Garten (2002). Potential increases in plant primary productivity with increasing moisture as well as reductions in microbial mineralization of the overall SOM with colder conditions can shift and drive the $\mathrm{C}$ balance in the soil towards net $\mathrm{C}$ accrual.

Of the three paired sites in Russia (Table 2), the Yamskaya site is probably the most representative and closely related to the three long-term chronosequences evaluated in this study. This is because Yamskaya and the three chronosequences are all geographically located within the Belgorod Oblast; hence, they share a more similar regional climate. It was striking that the afforested soil at the Yamskaya site had a soil C accretion even greater than the native grassland reference, which strongly indicated the high capacity of shelterbelts to sequester $\mathrm{C}$ even beyond the capacity of the corresponding native ecosystem (Table 2). After noticing this finding, it can also be anticipated that although the drier Kamennaya site showed at the present the slowest soil $\mathrm{C}$ accretion following afforestation of SOM-depleted croplands (i.e., $5 \%$ of $\mathrm{C}$ restoration, Table 2), it is possible that in the long term this drier environment can gradually sequester even more soil $\mathrm{C}$ than the moist sites located in Belgorod Oblast (e.g., Yamskaya). This is suggested as the Kamennaya site exhibited the highest soil $\mathrm{C}$ storage when comparing across all the native grasslands compiled in our study (i.e., $152.5 \mathrm{Mg} \mathrm{Cha}^{-1}$; Table 2 and Fig. 2).

\subsection{Turnover rates of soil carbon as a function of land use changes}

This study clearly confirms that the long-term dynamics of soil $\mathrm{C}$ is consistently nonlinear, either during decline or accumulation of soil $\mathrm{C}$ as a function of land use choices. As deliberated earlier by Post and Kwon (2000) and Garten (2002), erroneously assuming linearity in depicting these trajectories of soil $\mathrm{C}$ would lead to underestimating the rates of soil $\mathrm{C}$ changes during the first decades following a land use conversion as well as overestimating the turnover rates of soil $\mathrm{C}$ after multiple decades once the ecosystem has actually reached stability and a balance between their $\mathrm{C}$ inputs and outputs. This latter notion essentially applies when long-term cropland or afforested fields have become mature (HernandezRamirez et al., 2011).

Earlier chronosequence and stable isotope analyses by Arrouays et al. (1995) in southwest France further support that land use effects on soil $\mathrm{C}$ changes take place rather quickly.
They reported that a new equilibrium in soil $\mathrm{C}$ storage was reached within only a few decades of a land use change from forest to annual croplands, and with about half of the $\mathrm{C}$ loss occurring rapidly within few years $(<10)$ of beginning cultivation (Arrouays et al., 1995). Similarly, as in our study, only a few decades seem to be required to reach equilibrium when switching from cropland to trees (Richter et al., 1999; Paul et al., 2002; Guo and Gifford, 2002). Likewise, comprehensive results by Dhillon and Van Rees (2017) depicting soil C accretion caused by afforestation in the Canadian Prairies can be interpreted as net $\mathrm{C}$ losses taking place over the first several years after tree planting and subsequently, an ensuing fast accrual of soil $\mathrm{C}$ until tree ages of about 35 years when new equilibria or $\mathrm{C}$ sequestration ceilings under afforestation can be reached. In our study, MRT of soil C beneath trees was in general determined to be about 2 decades (Fig. 6). Furthermore, the evaluation of our two scenarios of asymptotic equilibria of $\mathrm{C}$ accrual in afforested soils (i.e., trajectories $\mathrm{A}$ and $\mathrm{B}$ in the normalized Russian chronosequences, Fig. 3) can provide the boundaries of faster vs. slower accretion rates of soil $\mathrm{C}$ with the corresponding MRTs of 1 vs. 3 decades.

In the case of long-term annual croplands in Russia, the soil C MRT of 100 years found in our study (i.e., associated with a $k$ rate constant of $0.010 \mathrm{yr}^{-1}$, Fig. 3) is comparable to findings by Huggins et al. (1998), who registered MRTs of 91 and 143 years in annual cropping systems in Minnesota but overall longer than a report by Collins et al. (1999), who found a wide range of MRTs between 18 to 96 years for sites with 8- to 33-year-old continuous maize cropping across the central United States, respectively.

It is noted that the exponential first-order trajectory of soil $\mathrm{C}$ turnover in the Russian chronosequences (Fig. 3) was captured better with Eq. (1) than the simplistic $\mathrm{C}_{(t)}=\mathrm{C}_{o} \times$ $e^{-k t}$ previously used by Hernandez-Ramirez et al. (2011). While Eq. (1) provided an $R^{2}$ of $90 \%$ (Fig. 3), $\mathrm{C}_{(t)}=\mathrm{C}_{o} \times$ $e^{-k t}$ returned an $R^{2}$ of $68 \%$ (data not shown). With two fitting parameters (i.e., $\mathrm{C}_{o}, \mathrm{C}_{\mathrm{e}}$ ), first-order kinetic modeling with Eq. (1) represented reasonably well the assumptions of steady state and new equilibrium at the end of the evaluated time series (Figs. 3, 6).

Further kinetics modeling efforts of soil $\mathrm{C}$ increases in afforested systems can take the form of two functional $\mathrm{C}$ pools where inputs and outputs to labile and stable SOM can be predicted (Arrouays et al., 1995; Garten, 2002; HernandezRamirez et al., 2009; Xiong et al., 2020). Preferentially accruing $\mathrm{C}$ into stable vs. labile SOM pools in afforested soils can be interpreted as tree-C contributions towards long- vs. short-term stability of soil C storage, respectively, with crucial ramifications for mitigation of future climate change (Laganiere et al., 2010; Hernandez-Ramirez et al., 2011; Deng et al., 2014). Future investigations can also focus on the protection and stabilization mechanisms of SOM as created by soil aggregate formation beneath trees (Kiani et al., 2017; Quesada et al., 2020). Once soils subjected to long-term annual cropping are converted to permanent vegetation, fungal 
hyphae can become an important means that mediates $\mathrm{C}$ accretion by enhancing soil aggregation (Jastrow et al., 1996; Kiani et al., 2017). Jastrow et al. (1996) indicated that fungal hyphae could improve macroaggregation and hence indirectly enhance $\mathrm{C}$ accrual. Using phospholipid fatty acid biomarkers, Kiani et al. (2017) identified a linkage between presence of fungal biomass and increases in hierarchical fractal aggregation specifically in forest soils, while this association was absent in the adjacent annually cropped soils in their study. Furthermore, Quesada et al. (2020) recently discussed the mechanisms for soil $\mathrm{C}$ accretion in tropical forests. In line with earlier findings by Wang et al. (2016), Quesada et al. (2020) stated that SOM physical protection provided by the formation of soil aggregates slows decomposition of SOM within aggregates; hence, it becomes a second layer of stabilization after realizing the primary SOM stabilizing effects caused by mineral surfaces of fine soil particles such as silt and clay. Further studies can focus on the effects of inherent mineralogy and texture as well as clay lessivage processes on $\mathrm{C}$ dynamics and storage in afforested soils (Chendev et al., 2020; Quesada et al., 2020).

\section{Conclusions}

Nonlinear turnover rates of soil $\mathrm{C}$ revealed an MRT of a century in long-term croplands as soil C slowly undergoes depletion and losses to the atmosphere. Likewise, when croplands were afforested, nonlinear accretion rates of soil $\mathrm{C}$ indicated an MRT of approximately 2 decades following afforestation. Soil $\mathrm{C}$ showed to be rapidly accrued as trees remove $\mathrm{CO}_{2}$ from the atmosphere and contribute $\mathrm{C}$ substrates for SOM accumulation and stabilization. While our study confirmed these substantial $\mathrm{C}$ accruals in the soils under the trees, the overall gain at the actual landscape scale will depend in part on the proportion of farmland dedicated to afforestation, with afforested areas typically accounting for up to $5 \%$ of the farmlands (Amadi et al., 2016).

Our focus on soil organic $\mathrm{C}$ behavior in soils under shelterbelts is only part of a broader range of studies evaluating the overarching impacts of agroforestry on soil quality and crop yield across the landscape. Beyond $\mathrm{C}$ sequestration, the benefits of shelterbelts can also be manifested in improving the local climate as well as increasing crop yields. Results collectively substantiated that in addition to multiple benefits by trees such as providing air quality, microclimate regulation, and erosion control (Sauer et al., 2007; Hernandez-Ramirez et al., 2012), C sequestration in afforested lands is a suitable means to proactively address and effectively mitigate ongoing climate change within a person's lifetime.

Data availability. Data are available upon request by contacting the corresponding author by email.
Author contributions. All authors contributed to study conceptualization. TJS, YGC and ANG implemented the field method as well as data curation. GHR conducted data analyses and drafted the article. All authors reviewed and commented on the article.

Competing interests. The authors declare that they have no conflict of interest.

Disclaimer. Publisher's note: Copernicus Publications remains neutral with regard to jurisdictional claims in published maps and institutional affiliations.

Acknowledgements. The authors are grateful for the valuable assistance provided by Kent Heikens, Kevin Jensen, David Denhaan, and Amy Morrow. The first author acknowledges early encouragements and beneficial exchange of ideas on the study subject with Cindy A. Cambardella - now sadly deceased. We sincerely appreciate the funding support as follows: from Natural Sciences and Engineering Research Council of Canada (NSERC) Discovery Grants program (2018-05717) as well as Alexander von Humboldt Foundation (Germany) (CAN - 1206917 - HFSTE) to Guillermo Hernandez-Ramirez; from the US Civilian Research and Development Foundation - Cooperative Grants Program (Project RUG1-7024-BL-11) to Thomas J. Sauer and Yury G. Chendev; and from Russian Science Foundation (Project 19-17-00056) for field sample collection and laboratory analyses within Russian sites to Yury G. Chendev and Alexander N. Gennadiev.

Financial support. This research has been supported by the Natural Sciences and Engineering Research Council of Canada (Discovery Grants program (grant no. 2018-05717)), the Alexander von Humboldt-Stiftung, CRDF Global (Cooperative Grants Program (grant no. RUG1-7024-BL-11)), and the Russian Science Foundation (grant no. 19-17-00056).

Review statement. This paper was edited by Carolina BoixFayos and reviewed by two anonymous referees.

\section{References}

Amadi, C. C., Van Rees, K. C. J., and Farrell, R. E.: Greenhouse gas mitigation potential of shelterbelts: Estimating farm-scale emission reductions using the Holos model, Can. J. Soil Sci., 97, 353 367, https://doi.org/10.1139/cjss-2016-0017, 2016

Arrouays, D., Balesdent, J., Mariotti, A., and Girardin, C.: Modelling organic carbon turnover in cleared temperate forest soils converted to maize cropping by using ${ }^{13} \mathrm{C}$ natural abundance measurements, Plant Soil, 173, 191-196, https://doi.org/10.1007/BF00011455, 1995.

Chendev, Y. G., Burras, C. L., and Sauer, T. J.: Transformation of forest soils in Iowa (United States) under the impact of longterm agricultural development, Eurasian Soil Sci., 45, 357-367, https://doi.org/10.1134/S1064229312040035, 2012. 
Chendev, Y. G., Novykh, L. L., Sauer, T. J., Petin, A. N., Zazdravnykh, E. A., and Burras, C. L.: Evolution of soil carbon storage and morphometric properties of afforested soils in the US Great Plains, Soil Carbon, 47, 475-482, https://doi.org/10.1007/978-3-319-04084-4_7, 2014.

Chendev, Y. G., Sauer, T. J., Gennadiev, A. N., Novykh, L. L., Petin, A. N., and Petina, V. I.: Accumulation of organic carbon in chernozems (Mollisols) under shelterbelts in Russia and the United States, Eurasian Soil Sci., 48, 43-53, 2015a.

Chendev, Y. G., Sauer, T. J., Hernandez-Ramirez, G., and Burras, C. L.: History of East European chernozem soil degradation: protection and restoration by tree windbreaks in the Russian steppe, Sustainability, 7, 705-724, https://doi.org/10.3390/su7010705, $2015 b$.

Chendev, Y. G., Gennadiev, A. N., Lukin, S. V., Sauer, T. J., Zazdravnykh, E. A., Belevantsev, V. G., and Smirnova, M. A.: Change of Forest-Steppe Chernozems under the Influence of Shelterbelts in the South of the Central Russian Upland, Eurasian Soil Sci., 53, 1033-1045, https://doi.org/10.1134/S1064229320080037, 2020.

Collins, H. P., Blevins, R. L., Bundy, L. G., Christenson, D. R., Dick, W. A., Huggins, D. R., and Paul, E. A.: Soil carbon dynamics in corn-based agroecosystems: Results from carbon13 natural abundance, Soil Sci. Soc. Am. J., 63, 584-591, https://doi.org/10.2136/sssaj1999.03615995006300030022x, 1999.

Curtin, D., Beare, M. H., Scott, C. L., Hernandez-Ramirez, G., and Meenken, E. D.: Mineralization of soil carbon and nitrogen following physical disturbance: a laboratory assessment, Soil Sci. Soc. Am. J., 78, 925-935, https://doi.org/10.2136/sssaj2013.12.0510, 2014.

Deng, Q., Cheng, X., Yang, Y., Zhang, Q., and Luo, Y.: Carbon-nitrogen interactions during afforestation in central China, Soil Biol. Biochem., 69, 119-122, https://doi.org/10.1016/j.soilbio.2013.10.053, 2014.

Dhillon, G. S. and Van Rees, K. C. J.: Soil organic carbon sequestration by shelterbelt agroforestry systems in Saskatchewan, Can. J. Soil Sci., 97, 394-409, https://doi.org/10.1139/cjss-2016-0094, 2017.

Follett, R., Paul, E., Leavitt, S., Halvorson, A., Lyon, D., and Peterson, G.: Carbon isotope ratios of Great Plains soils and in wheat-fallow systems, Soil Sci. Soc. Am. J., 61, 1068-1077, https://doi.org/10.2136/sssaj1997.03615995006100040012x, 1997.

Garten, C. T.: Soil carbon storage beneath recently established tree plantations in Tennessee and South Carolina, USA, Biomass Bioenerg., 23, 93-102, https://doi.org/10.1016/S09619534(02)00033-8, 2002.

Gregorich, E. G., Janzen, H., Ellert, B. H., Helgason, B. L., Qian, B., Zebarth, B. J., Angers, D. A., Beyaert, R. P., Drury, C. F., Duguid, S. D., and May, W. E.: Litter decay controlled by temperature, not soil properties, affecting future soil carbon, Glob. Change Biol., 23, 1725-1734, https://doi.org/10.1111/gcb.13502, 2017.

Guenette, K. G. and Hernandez-Ramirez, G.: Tracking the influence of controlled traffic regimes on field scale soil variability and geospatial modeling techniques, Geoderma, 328, 66-78, https://doi.org/10.1016/j.geoderma.2018.04.026, 2018.
Guo, L. B. and Gifford, R. M.: Soil carbon stocks and land use change: a meta analysis, Glob. Change Biol., 8, 345-360, https://doi.org/10.1046/j.1354-1013.2002.00486.x, 2002

Hebb, C., Schoderbek, D., Hernandez-Ramirez, G., Hewins D., Carlyle, C. N., and Bork, E.: Soil physical quality varies among contrasting land uses in Northern Prairie regions, Agr. Ecosyst. Environ., 240, 14-23, https://doi.org/10.1016/j.agee.2017.02.008, 2017

Hernandez-Ramirez, G., Brouder, S. M., Smith, D. R., and Van Scoyoc, G. E.: Carbon and nitrogen dynamics in an Eastern Corn Belt soil: N source and rotation, Soil Sci. Soc. Am. J., 73, 128137, https://doi.org/10.2136/sssaj2007.0381, 2009.

Hernandez-Ramirez, G., Sauer, T. J., Cambardella, C. A., Brandle, J. R., and James, D. E.: Carbon sources and dynamics in afforested and cultivated Corn Belt soils, Soil Sci. Soc. Am. J., 75, 216-225, https://doi.org/10.2136/sssaj2010.0114, 2011.

Hernandez-Ramirez, G., Trabue, S. L., Sauer, T. J., Pfeiffer, R. L., and Tyndall, J. C.: Odor mitigation with tree buffers: swine production case study, Agr. Ecosyst. Environ., 149, 154-163, https://doi.org/10.1016/j.agee.2011.12.002, 2012.

Hu, Y., Zeng, D., Chang, S., and Mao, R.: Dynamics of soil and root $\mathrm{C}$ stocks following afforestation of croplands with poplars in a semi-arid region in northeast China, Plant Soil, 368, 619627, https://doi.org/10.1007/s11104-012-1539-2, 2013.

Huggins, D. R., Clapp, C. E., Allmaras, R. R., Lamb, J. A., and Layese, M. F.: Carbon dynamics in cornsoybean sequences as estimated from natural carbon13 abundance, Soil Sci. Soc. Am. J., 62, 195-203, https://doi.org/10.2136/sssaj1998.03615995006200010026x, 1998.

Jastrow, J. D.: Soil aggregate formation and the accrual of particulate and mineral-associated organic matter, Soil Biol. Biochem., 28, 665-676, https://doi.org/10.1016/0038-0717(95)00159-X, 1996.

Khaleel, A. A., Sauer, T. J., and Tyndall, J. C.: Changes in deep soil organic carbon and soil properties beneath tree windbreak plantings in the US Great Plains, Agroforest. Syst., 94, 565-581, https://doi.org/10.1007/s10457-019-00425-0, 2020.

Kiani, M., Hernandez-Ramirez, G., Quideau, S., Smith, E., Janzen, H., Larney, F., and Puurveen, D.: Quantifying sensitive soil quality indicators across contrasting long-term land management systems: crop rotations and nutrient regimes, Agr. Ecosyst. Environ. 248, 123-135, https://doi.org/10.1016/j.agee.2017.07.018, 2017.

Kiani, M., Hernandez-Ramirez, G., and Quideau, S.: Spatial variation of soil quality indicators as a function of land use and topography, Can. J. Soil Sci., 100, 463-478, https://doi.org/10.1139/cjss-2019-0163, 2020.

Laganiere, J., Angers, D. A., and Pare, D.: Carbon accumulation in agricultural soils after afforestation: a meta-analysis, Glob. Change Biol., 16, 439-453, https://doi.org/10.1111/j.13652486.2009.01930.x, 2010.

Li, D., Niu, S., and Luo, Y.: Global patterns of the dynamics of soil carbon and nitrogen stocks following afforestation: A meta-analysis, New Phytol., 195, 172-181, https://doi.org/10.1111/j.1469-8137.2012.04150.x, 2012.

Li, J.C., Hernandez-Ramirez, G., Kiani, M., Quideau, S., Smith, E., Janzen, H., Larney, F., and Puurveen, D.: Soil organic matter dynamics in long-term temperate agroecosystems: rotation 
and nutrient addition effects, Can. J. Soil Sci., 98, 232-245, https://doi.org/10.1139/cjss-2017-0127, 2018.

Martin, A., Mariotti, A., Balesdent, J., Lavelle, P., and Vuattoux, R.: Estimate of organic matter turnover rate in a savannah soil by $13 \mathrm{C}$ natural abundance, Soil Biol. Biochem., 22, 517-523, https://doi.org/10.1016/0038-0717(90)90188-6, 1990.

Mary, B., Clivot, H., Blaszczyk, N., Labreuche, J., and Ferchaud. F.: Soil carbon storage and mineralization rates are affected by carbon inputs rather than physical disturbance: evidence from a 47year tillage experiment, Agr. Ecosyst. Environ., 299, 1069723, https://doi.org/10.1016/j.agee.2020.106972, 2020.

Mellor, N. J., Hellerich, J., Drijber, R., Morris, S. J., Stromberger, M. E., and Paul, E. A.: Changes in ecosystem carbon following afforestation of native sand prairie, Soil Sci. Soc. Am. J., 77, 1613-1624, https://doi.org/10.2136/sssaj2012.0327, 2013.

Parry, M., Parry, M. L., Canziani, O., Palutikof, J., Van der Linden, P., and Hanson, C.: Climate change 2007-impacts, adaptation and vulnerability: Working group II contribution to the fourth assessment report of the IPCC, Cambridge University Press, Cambridge, United Kingdom, 2007.

Paul, K. I., Polglase, P. J., Nyakuengama, J. G., and Khanna, P. K.: Change in soil carbon following afforestation, Forest Ecol. Manag., 168, 241-257, https://doi.org/10.1016/S03781127(01)00740-X, 2002.

Paustian, K., Parton, W. J., and Persson J.: Modeling soil organic matter in organic-amended and $\mathrm{N}$-fertilized long-term plots, Soil Sci. Soc. Am. J., 56, 476-488, https://doi.org/10.2136/sssaj1992.03615995005600020023x, 1992.

Post, W. M. and Kwon, K. C.: Soil carbon sequestration and landuse change: processes and potential, Glob. Change Biol., 6, $317-$ 327, https://doi.org/10.1046/j.1365-2486.2000.00308.x, 2000.

Quesada, C. A., Paz, C., Oblitas Mendoza, E., Phillips, O. L., Saiz, G., and Lloyd, J.: Variations in soil chemical and physical properties explain basin-wide Amazon forest soil carbon concentrations, Soil, 6, 53-88, https://doi.org/10.5194/soil-6-53-2020, 2020.
Richter, D. D., Markewitz, D., Trumbore, S. A., and Wells, C. G.: Rapid accumulation and turnover of soil carbon in a re-establishing forest, Nature, 400, 56-58, https://doi.org/10.1038/21867, 1999.

Sauer, T. J., Cambardella, C. A., and Brandle, J. R.: Soil carbon and tree litter dynamics in a red cedar-Scotch pine shelterbelt, Agroforest. Syst., 71, 163-174, https://doi.org/10.1007/s10457007-9072-7, 2007.

Sauer, T. J., James, D. E., Cambardella, C. A., and HernandezRamirez, G.: Soil properties following reforestation or afforestation of marginal cropland, Plant Soil, 360, 375-390, https://doi.org/10.1007/s11104-012-1258-8, 2012.

Thilakarathna, S. K. and Hernandez-Ramirez, G.: How does Management Legacy, Nitrogen Addition and Nitrification Inhibition Impact Soil Organic Matter Priming and Nitrous Oxide Production?, J. Environ. Qual., 50, 78-93, https://doi.org/10.1002/jeq2.20168, 2021.

Wang, F., Zhu, W., and Chen, H.: Changes of soil C stocks and stability after 70-year afforestation in the Northeast USA, Plant Soil, 401, 319-329, https://doi.org/10.1007/s11104-015-2755-3, 2016.

Xiong, X., Zhang, H. L., Deng, Q., Hui, D. F., Chu, G.W., Meng, Z., Zhou, G. Y., and Zhang, D. Q.: Soil organic carbon turnover following forest restoration in south China: Evidence from carbon isotopes, Forest Ecol. Manag., 462, 117988, https://doi.org/10.1016/j.foreco.2020.117988, 2020.

Zhang, Q. Y., Jia, X. X., Wei, X. R., Shao, M. A., Li, T. C., and Yu, Q.: Total soil organic carbon increases but becomes more labile after afforestation in China's Loess Plateau, Forest Ecol. Manag, 461, 117911, https://doi.org/10.1016/j.foreco.2020.117911, 2020. 